\title{
Global Standards of Constitutional Law: Epistemology and Methodology
}

\author{
Maxime St-Hilaire ${ }^{1}$
}

\begin{abstract}
Just as it led the philosophy of science to gravitate around scientific practice, the abandonment of all foundationalist aspirations has already begun making political philosophy into an attentive observer of the new ways in which constitutional law is practiced. Yet paradoxically, lawyers and legal scholars are not those who understand this the most clearly. Beyond analyzing the jurisprudence that has emerged from the expansion of constitutional justice, and taking into account the development of international and regional law, the ongoing globalization of constitutional law requires comparing the constitutional laws of individual nations. Following Waldron, the product of this new legal science can be considered as ius gentium. This legal science is not as well established as one might like to think. But it can be developed on the grounds of the practice that consists in ascertaining standards. As abstract types of best "practices" (and especially norms) of constitutional law from around the world, these are only a source of law in a substantive, not a formal, sense. They thus belong to what I should like to call a "second order legal positivity." In this article I will undertake, both at a methodological and an epistemological level, the development of a model for ascertaining global standards of constitutional law.
\end{abstract}

\section{Keywords}

Constitutional Law- Legal Science - Sources of Law (formal and substantive) - Legal Standards - Ius Gentium - Legal Principles - Comparative Law - Venice Commission - Rule of Law Rule of Law Indicators and Factors - Reflective Equilibrium - Interpretive Equilibrium - John Rawls - Ronald Dworkin - Jeremy Waldron

\footnotetext{
${ }^{1}$ Assistant Professor, Faculty of Law, University of Sherbrooke. Translation by Léonid Sirota, JSD Candidate, NYU. A slightly different French version of this paper is forthcoming as a book chapter: "Standards constitutionnels mondiaux: épistémologie et méthodologie", in M Disant, G Lewkowicz and P Türk (eds), Vers des standards constitutionnels mondiaux (Paris: LGDJ, 2015).
} 


\section{Table of Contents}

Introduction

1. Epistemology

1.1 From Anti-Legal Blindness to the (Re)discovery of Law as a Science

1.2 From Reflective Normative Equilibrium to Law as Interpretive Equilibrium

1.3 Second Order Legal Positivity

1.4 From National Legal Principles to ius gentium

2. Methodology

2.1 Rule of Law

2.2 From Principles to Standards

2.3 Comparative Law, the Search for Functional Equivalents, and Typology

2.4 From Typology to Valuing, and from Standards (back) to Principles

2.5 Actors

Conclusion 
Just as it led the philosophy of science to gravitate around scientific practice, the abandonment of all foundationalist aspirations has already begun making political philosophy into an attentive observer of the new ways in which constitutional law is practiced. The new science of constitutional law may well come to feature at the forefront of the discussions of Justice as a formal, paramount, and modern aspect of the Good. ${ }^{2}$ Yet paradoxically, jurists, that is, lawyers and legal scholars as opposed to philosophers, are not, with a few exceptions, ${ }^{3}$ those who understand this the most clearly.

Indeed, it is still among too few of them that "Radbruch's claim that the year 1945 was a clean break in the history of law, in that it put an end to the reign of a hated positivism and sounded the rebirth of natural law theory, is no longer accepted without qualification." ${ }^{4}$ In any event, given the prevalent legal epistemology, the normative significance of the positivization of human rights, in international law but also in the law of multiple nations, seems destined to largely escape the jurists. Does a mere gain in effectiveness ${ }^{5}$ suffice to explain why it is "an undeniable progress" that, in the post-World War II period, positive law has begun "to perform the function theoretically assigned to natural law"? ${ }^{6}$ More precisely, why should we regard as progress the overcoming, in the last sixty years, of the opposition between natural law and (a certain restrictive conception of) positive law? ${ }^{7}$ Questions of this sort seem incomprehensible to jurists. Either they are mistaken, or they should be addressed to others.

At the risk of over-generalizing, we might say that in its current state, legal science presents the following epistemological tryptich. It is said that, beyond the letter of the law and the cases, the

\footnotetext{
${ }^{2}$ See especially John Rawls, A Theory of Justice, rev ed (Cambridge, MA: Belknap Press, 1999) at 30 and Part III: "Ends" [Rawls, Theory]

${ }^{3}$ See espeically DP Kommers, "The Value of Comparative Constitutional Law", (1976) 9 John Marshall Journal of Practice \& Procedure 685 at 692 (arguing that "comparative law can be helpful in the quest for a theory of the public good and right political order. It can represent a disinterested quest for a public philosophy and a statement of the rights and duties that would be assigned in a more perfect constitutional polity.").

${ }^{4}$ Luc Heuschling, État de droit, Rechtsstaat, Rule of Law (Paris: Dalloz, 2002) at 32-33 (translation mine) (Heuschling adds that "[t] he antipositivist wave actually draws its sources in the famous methodological quarrel of Weimar, whose echo was indeed still heard under the Third Recih. Nazi jurists, whose discourse was not without some analogies to the theory of natural law which was "reborn" after 1945, tirelessly asserted the existence of an inextricable relationship between law and morality.")

${ }^{5}$ See V Champeil-Desplats, "Effectivité et droits de l'homme : approche théorique", in V Champeil-Desplats and D Lochak (eds), À la recherche de l'effectivité des droits de l'homme, (Paris: Presses universitaires de Paris 10, 2008) 11.

${ }^{6}$ Mireille Delmas-Marty, Vers un droit commun de l'humanité, Conversation with Philippe Petit, 1995 (Textuel, 2005) at 78.

${ }^{7}$ Ibid.
} 
legal scholar, who by definition ought to possess a knowledge different from that of the legal practitioner, has three options: (1) to seek (more or less hopelessly) the true knowledge about law in any discipline, preferably an empirical one, other than law itself; (2) to resign him- or herself (more or less cynically) to adhere to a purely "political" conception of the law (such as relativism, decisionism, culturalism, existentialism, etc.); or, (3) to resolve (more or less naïvely) on going back to natural law, that is to say, the natural law of the philosophers, the idea of "philosophical foundations" of the law.

Beyond analyzing the jurisprudence that has emerged from the expansion of constitutional justice, ${ }^{8}$ and taking into account the development of international and regional law, the ongoing globalization of constitutional law requires comparing the constitutional laws of individual nations. ${ }^{9}$ The product of this new legal science can be considered as ius gentium. Jeremy Waldron asks the following question: "What if [ius gentium] is largely unknown and unitelligible to those who pride themselves on the study of moral ideas but is studied and used by those who trained and pride themsleves on an understanding of law?"10 For my own part, I would answer that in that case, it is high time that the jurists, as bearers of this knowledge, knew better how to articulate, situate, embrace, spread, and draw upon it.

For the moment, however, the new science of ius gentium is not as well established as one might like to think - not only on the level of methodology, but also on that of epistemology. Reference to foreign law and more systematic comparison of laws follow a variety of logics. Sometimes these logics are in competition, while at other times they are situated on different levels and could thus be combined, were it not for the fact that they are also, most often, governed by different epistemologies. Even the Waldronian model of ius gentium, epistemologically well-developed though it is, is not free from methodological ambiguities. For this reason, in this article I will undertake, both at a methodological and an epistemological level, the development of a model for ascertaining standards.

A terminological clarification is in order. As "best practices" among which we can normally count typologies of legal norms, the global standards of constitutional law do not fit within the definition of legal standards which a dictionary of legal theory might provide. When I speak of a global standard of constitutional law, I do not mean a "term or expression within a legal rule or document that requires evaluation or assessment." The standards to which I am referring are not norms of positive law the contents or object of which "are only very partially legal," which "manifestly draws upon benchmarks that can (or must?) be located outside the law itself," such as

\footnotetext{
${ }^{8}$ O Jouanjan, "Histoire de la science du droit constitutionnel”, in M Troper et D Chagnollaud (eds), Traité international de droit constitutionnel, (Paris: Dalloz, 2012), vol 1, Théorie de la constitution 69 at 107.

${ }^{9}$ Sujit Choudhry, "Globalization in Search of Justification: Toward a Theory of Comparative Constitutional Interpretation”, (1999) 74:3 Indiana LJ 819 at 821.

${ }^{10}$ Jeremy Waldron, "Partly Laws Common to All Mankind": Foreign Law in American Courts, (New Haven, CT: Yale University Press, 2012) at 74 [Waldron, Laws Common].
} 
"local habits, custom, or simply human reason." Nor do I mean, "more generally," any "notion of the legal language with an indeterminate or variable contents," or a "vague concept" that opens up, within a legal rule, an "area of indeterminacy that must be covered by an act of evaluation.",11 Besides, as abstract types of best "practices" (and especially norms) of constitutional law from around the world, that is to say drawn from a multitude of systems of positive law and simplified, the standards with which I am concerned here are only a source of law in a substantive, not a formal, sense. They thus belong to what I should like to call a "second order legal positivity."

\section{EPISTEMOLOGY}

Is it not somehow absurd that, even as the conditions of thought are such that political philosophers are increasingly finding some of their best arguments in the international and constitutional instruments, laws, and judicial decisions, in many countries legal scholars measure the "scientificity" of their scholarship by the distance that separates it from legal scholarship? Ever since legal systems were nationalized, the European ius commune made up of Roman and canon law vanished, ${ }^{12}$ and the social sciences consolidated, the legal science has been in search of itself. Should it become a descriptive, positive-empricial, or historical-normativist discipline? Or should it wander over to the pure realm of normative philosophy, even at the risk of becoming philosophy of law without knowledge of law?

\subsection{From Anti-Legal Blindness to the (Re)discovery of Law as a Science}

The great projects which, mostly in the last century, aimed at making law into a purely descriptive science all failed. The most radical theories of "law as fact" are so many illusions. Indeed, their principal authors all defended, either concurrently or subsequently, a conception of law as an essentially normative phenomenon. ${ }^{13}$ As for law as a system of positive norms, the scholarly study of its contents never yielded any objective science of "propositions of law" (Rechtssätze) as pure "Sollen" describing such norms and their relationship with facts. ${ }^{14}$ The positive heritage that the epistemological "great projects" of the $20^{\text {th }}$ century bequeathed to the science of law consists mostly of the social-legal approaches, not always said to be truly "interdisciplinary," whose influence on the social sciences has been largely limited to the economic analysis of law. ${ }^{15}$ Another of these approaches is "legal pluralism," which is wrongly

\footnotetext{
${ }^{11}$ P Orianne, "Standard juridique", in A-J Arnaud et al (eds), Dictionnaire encyclopédique de théorie et de sociologie du droit, $2^{\text {nd }}$ ed, (Paris: LGDJ, 1993) at 581-582.

12 RH Helmholz, "Western Canon Law", in J Witte, Jr and FS Alexander (eds), Christianity and Law: An Introduction, (Cambridge: Cambridge University Press, 2008) 71.

${ }^{13}$ Maxime St-Hilaire, La lutte pour la pleine reconnaissance des droits ancestraux. Problématique juridique et enquête philosophique, (Cowansville : Yvon Blais, forthcoming in 2015) [St-Hilaire, Lutte].

${ }^{14}$ Hans Kelsen, Pure Theory of Law, $2^{\text {nd }}$ éd (rev \& enlarged) (Bekeley, CA \& Los Angeles: University of California Press, 1967) at 72-73.

${ }^{15}$ Richard A Posner, "Symposium: Law, Knowledge, and the Academy: Legal Scholarship Today", (2002) 115:5 Harv L Rev 1314.
} 
believed to be the starting point and the obligatory framework for any study of "interactions between legal orders" and whose scientifically descriptivist claims, at best, make it miss the main normative issues; at worst, they serve to mask a poorly-defended anti-state position. ${ }^{16}$ Faced with the relative impracticability of a narrowly descriptive legal scientism, the ineradicability of the law's normative issues, and the horror of the Holocaust, the jurists, most often forgetting Nazism's legal anti-positivism, ${ }^{17}$ have generally tended to return to natural law, ${ }^{18}$ turning towards philosophy or, more precisely, towards a conception of philosophy that is no longer sustainable. If the textbook market and university curricula which largely drive it are any evidence, the already outdated idea of "philosophical foundations of law" is even more popular among the jurists than it is among philosophers.

What matter, then, that in his discussion with the "sociologist" Max Weber, whose epistemological and methodological work in fact postdates his own, the jurist Georg Jellinek should "not be considered as a sort of disciple of the great master, but as a full partner whose thought would, on many essential points — the best known of which is theory of 'type' — inspire Weber's own work"? ${ }^{19}$ What matter that, contrary to a widespread idea, Émile Durkheim did not see in the law, and notably in the legal sanction, a phenomenon to be explained by sociology, so much as a magnificent observatory of society? ${ }^{20}$ What matter it to know that Karl Marx failed to acknowledge the debt which historical materialism, certainly one of the most sociological of his ideas, owed to the Historical school of law? ${ }^{21}$ What matter that, well before he deduced "law" from morals, Kant compared the "transcendental deduction" to what the jurists call the "quid juris," contrasting it to the "quaestio facti"? ${ }^{22}$ What matter, indeed, that the thinker of the conditions of the possibility of moral knowledge and action spoke of reason as a "tribunal," ultimately bringing all philosophical questions close to a quid juris? What matter that the critical philosophy which Kant founded and Fichte completed is "essentially legal in its method, up to and including in the realm of theory of knowledge? ${ }^{23}$ What matter all of this, since jurists continue, more or less consciously but nevertheless massively, to attribute to any "external" perspective on the law a perceptiveness that stands in stark contrast with the merely superficial if not specious knowledge thought to be the most that an "internal" perspective can possibly

\footnotetext{
${ }^{16}$ Maxime St-Hilaire, “The Study of Legal Plurality outside 'Legal Pluralism': the Future of the Discipline?”, in Helge Dedek and Shauna Van Praagh (eds), Stateless Law: Evolving Boundaries of a Discipline, (Ashgate, forthcoming in 2015).

${ }^{17}$ Heuschling, supra note 4.

${ }^{18}$ Voir Gustav Radbruch, “Gezetliches Unrecht und übergesetzliches Recht”, (1946:1) Süddeutsches JuristenZeitung 105.

${ }^{19}$ O Jouanjan, "Préface : Georg Jellinek ou le juriste philosophe” in Georg Jellinek, L'État moderne et son droit, L'État moderne et son droit, reprint, G Fardis, transl (1911-1913) (Paris: Panthéon-Assas/LGDJ, 2005$)$ vol 1, 35.

${ }^{20}$ Voir Émile Durkheim, De la division du travail social (Presses Universitaires de France, 2007); David Garland, Punishment and Modern Society: A Study in Social Theory, (Chicago: University of Chicago Press, 1990) at 23.

${ }^{21}$ N Levine "The German Historical School of Law and the Origins of Historical Materialism", (1987) 48:3 J of the History of Ideas 431.

${ }^{22}$ Immanuel Kant, The Critique of Pure Reason, JMD Meikeljohn, transl (Auckland, NZ: The Floating Press, 2007) at $158-60$.

${ }^{23}$ F Fischbach, Fondement du droit naturel. Fichte, (Ellipses, 2000) at 15.
} 
provide. In Canada, for instance, the public financing of university research, as well as, by way of consequence, the training of researchers in this area, still rely on the conclusions of the 1983 "Arthurs Report," a document that mostly evokes the scientistic enthusiasm of the great epistemological projects for the law, but which, at the same time, obeys the traditional conception of philosophy as the "mother of sciences.",

In some legal circles, notably within law faculties, it is thus said that jurists "should abandon any pretense of a distinctive and autonomous analytic method" of their own, ${ }^{25}$ and instead see what is available from the catalogue of "true" epistemologies. The attitude which this virtual shopping mall favours is that of legal relativism. ${ }^{26}$ Now, "[r]elativism is usually a dirty word. But this sense of law's relativity is quite settled in many people's minds," as Waldron too observes. ${ }^{27}$ Among these people are jurists who, at the same time,

have their own particular approach. It is not primarily empirical, though it leaves room for the insertion of empirical information at various points. Neither is it just moral argument or advocacy. It is a method of analysis: taking an issue apart and reformulating it step by step as a series of conditions and tests that apply various nested, interlocking, and sometimes competing principles. $^{28}$

To rely on the standard-setting method to position legal science as an alternative to relativist sterility - this is really my objective. Due to the way in which, starting no doubt with Bentham, the distinction between law and morality structures debates in legal philosophy, and more specifically because the first of these concepts came to be identified "with power and practice in the context of single, well-organized political communities, there is a tendency also to think that by moving outside those bounds we must be moving in the direction of natural law." ${ }^{29}$ Yet the distinction between the law that is and the law that ought to be need not coincide with that between law and morality, notably because law is not only the product of the various positive systems of formal sources, but also a normative science. Thus the ascertainment of global standards of constitutional law belongs not to a narrow but to a broad conception of legal positivism. This conception posits the existence, within a space which might metaphorically be

\footnotetext{
${ }^{24}$ Consultative Group on Research and Education in Law, Law and Learning: Report to the Social Sciences and Humanities Research Council of Canada (Ottawa: Social Sciences and Humanities Research Council of Canada, 1983).

${ }^{25}$ Waldron, Laws Common, supra note 10, at 95.

${ }^{26}$ See M Mahlmann, "Human Dignity and Autonomy in Modern Constitutional Orders", in Michel Rosenfeld and András Sajó (eds), The Oxford Handbook of Comparative Constitutional Law, (Oxford: Oxford University Press, 2012) 370 at 375 (arguing that "[f]or many, the only intellectually respectable position is therefore one or another form of relativism founding normative arguments in the last instance on cultural traditions, social semantics, discourse formations, operations of social systems, shifting narratives, or exchangeable final languages").

${ }^{27}$ Waldron, Laws Common, supra note 10, at 16.

${ }^{28} \mathrm{Ibid}$, at $93-94$.

${ }^{29} \mathrm{Ibid}$, at 42.
} 
located in between the philosophical "natural law" and the positive law strictly understood as the product of only formal sources, of what I would like to call a "second order legal positivity."

The claim that the science of constitutional law is a second order positivity is, in turn, dependent on the successive validity of three others, which will at times run together in the following section. The first is non-foundationalism - the claim that normative thought is not "founded" on anything absolute that is foreign or exterior to, or, in other words, independent of, the ordinary experience and beliefs of human beings. ${ }^{30}$ The second is non-relativism - the claim that neither the plurality of the forms of implementation of justice nor the rejection of the idea of assured philosophical foundations prevents the use of reason in the realm of the ought; a use which must henceforth consist in a coherent reconstruction of socially constituted normative intuitions, it being understood that all reconstructions need not be equally coherent and non-counter-intuitive, and thus of equal value. The third is legalism - the claim that one of if not the most universal, the least counter-intuitive, the most coherent, and the most effective of such reconstructions could well be legal science, including the science of constitutional law, which deals with the essential characteristics of the political "ought" - it being understood that this science possesses a greater degree of positivity than philosophy but a smaller one than positive law stricto sensu.

\subsection{From Reflective Normative Equilibrium to Law as Interpretive Equilibrium}

Martha Nussbaum explains that, although "[m] any critics of universalism in ethics are really critics of metaphysical realism who assume that realism is a necessary basis for universalism ..., this assumption is false," 31 simply because "universal ideas of the human do arise within history and from human experience, and can ground themselves in experience." 32 Nussbaum distinguishes the modern type of scepticism from the ancient, much as Ronald Dworkin separates external scepticism from the internal sort (a term which he applies to the "critical legal studies" movement). Philosophical anti-realism does not at require, by itself, normative scepticism. ${ }^{33}$ Indeed, Nussbaum and Dworkin are far from alone in making this claim. ${ }^{34}$ While not all those

\footnotetext{
${ }^{30}$ There also exists a complete version of non-foundationalism, which extends to theoretical thought. While I am inclined to agree with it, this article does not depend on it. On this point, see especially the works of Ludwig Wittgenstein, Willard Van Orman Quine, Wilfrid Sellars, Donald Davidson et Richard Rorty.

${ }^{31}$ See Martha Nussbaum, "Human Capabilities, Female Human Beings", in Martha Nussbaum and Jonathan Glover (eds), Women, Culture and Development: A Study of Human Capabilities, (New York: Oxford University Press, 1995), at 67-68.

${ }^{32}$ Ibid at 69.

${ }^{33}$ See Martha Nussbaum, "Skepticism about Practical Reason in Literature and the Law" (1994) 107:3 Harv L Rev 714; Ronald Dworkin, Law's Empire, (Cambridge, MA: Belknap Press, 1986) at 76-85 and 266-275 [Dworkin, Empire]; Ronald Dworkin, Justice for Hedgehogs (Belknap Press, 2011) at 25 ("I do reject Archimedean skepticism: skepticism that denies any basis for itself in morality or ethics.") [Dworkin, Hedgehogs].

${ }^{34}$ See John Rawls "Outline of a Decision Procedure for Ethics", (1951) 60:2 Philosophical Review 177; Thomas Nagel, The Possibility of Altruism, (Princeton, NJ: Princeton University Press, 1970) ; Simon Blackburn, Spreading the Word: Groundings in the Philosophy of Language, (New York: Oxford University Press, 1984); Jeremy Waldron, "The Irrelevance of Moral Objectivity", in Law and Disagreement, (New York: Oxford University Press, 1999) 164.
} 
who reject normative scepticism admit the possibility of a universal level of overlap, such thinkers generally agree that post-metaphysical normative thought is anchored in a diffuse sociohistorical normativity. Non-foundationalism thus brings with it a variable degree of pluralism, which substitutes itself, either to monism or, at least, a thoroughgoing form of monism. The false belief that the end of metaphysical realism had to carry with it that of all normative universalism conceals a false equation between universalism, monism, and reason. This misapprehension is obviously in no small part due to Isaiah Berlin who, as Waldron points out,

managed to convince a lot of smart people that because there are genuine tradeoffs to be made among a plurality of values and because there is no guarantee that the various values we treasure fit neatly into a single rational, preordained scheme, we should therefore eschew the idea of reason when it comes to figuring how the tangled priorities of our values play out in difficult individual cases. $^{35}$

Berlin even "made us all think that anyone who said the contrary was some sort of totalitarian. ... But we don't need to abandon the idea that these are issues of reason just because the reasoning of one person doesn't yield the same results as the reasoning of another." ${ }^{36}$ As Dworkin explains, uncertainty does not equal (internal) skepticism. ${ }^{37}$ While universalism is an issue for law as it is for other normative realms, Mahlmann is right to suggest that it does not call into question "the variety of interpretations of shared legal concepts or the importance of context for the understanding of legal precepts. ... The interesting question is ... whether all these conceptions are of equal normative plausibility." ${ }^{38}$ Waldron, for his part, chooses not use the word "universalism," arguing that "it is an objective truth notion, and it says that the truth is the same everywhere, whatever people happen to believe." 39 But this is merely a matter of connotation. The non-foundationalist universal, with its social-historical rather than dogmatic anchoring, has absolutely no need to become metaphysically realist or "monist" at every level — it only needs to accept a reasonable pluralism of implementations. This is why, for my part, I will speak of universalism.

In his last, posthumous, book, Religion without God, Dworkin, being of the view that the "thing in itself" is no more necessary to the natural sciences than moral realism to the normative usage of reason, argues that "we accept our most basic scientific and mathematical capacities finally as a matter of faith." ${ }^{\circ 0}$ What he calls the religious attitude entails doing the same with normative competencies. To be sure, "we disagree markedly about goodness, right, beauty, and justice" and

\footnotetext{
${ }^{35}$ Waldron, Laws Common, supra note 10, at 220.

${ }^{36}$ Ibid.

${ }^{37}$ Dworkin, Hedgehogs, supra note 33, chap 5.

${ }^{38}$ Mahlmann, supra note 26, at 373-374.

${ }^{39}$ See Waldron, Laws Common, supra note 10, at 117.

${ }^{40}$ Ronald Dworkin, Religion Without God, (Cambridge, MA; London: Harvard University Press, 2013) at 17 [Dworkin, Religion].
} 
"have no agreed standards for moral or other forms of reasoning about value," as we do for "scientific argument and valid mathematical demonstration." 41 The realm of values consists, formally as well as substantively, of "essentially contested concepts," to borrow Walter Gallie's term. ${ }^{42}$ Yet this difference, says Dworkin, is not determinative, since "interpersonal agreement is not an external certification in any domain." "(One might add, along with Michael Moore, that neither is the absence of agreement proof of the inexistence of an external reality. ${ }^{44}$ ) A second, and more significant, difference is that, in the realm of values "faith means something more, because our convictions about value are emotional commitments as well and, whatever tests of coherence and internal support they survive, they must feel right in an emotional way as well., ${ }^{, 45}$ This argument follows not only Nussbaum, but also a long tradition of thought, going back to Aristotle. $^{46}$

A complete and coherent reconstruction of all our scattered ethical, moral, political, and legal convictions resulting from multiple back-and-forths: one recognizes, in the faith which not only Dworkin but a whole constellation of thinkers had in the normative competencies of a human person, a faith in the method, generally attributed to John Rawls, of reflective equilibrium. ${ }^{47}$ Although Rawls's method was not, at the time, as unprecedented as it is often supposed, ${ }^{48}$ the quality of its articulation and the impact it had mean that it was a turning point in the history of normative thought. This method is meant to respect the scientific knowledge about human beings and society, without however conflating the possible and the desirable. It seeks at the same time to anchor itself in, and to prove itself through, our second order normative intuitions regarding institutions. ${ }^{49}$ If not clearly in his 1971 book, ${ }^{50}$ then certainly no later than $1975,{ }^{51}$ Rawls took

\footnotetext{
${ }^{41}$ Ibid.

${ }^{42}$ WB Gallie, "Essentially Contested Concepts", (1955-1956) 56 Proceedings of the Aristotelian Society 167.

${ }^{43}$ Dworkin, Religion, supra note 40, at 17.

${ }^{44}$ M. Moore, « Moral Reality », Wisconsin Law Review, vol. 1982, no 6, p. 1061-1156, aux pages 1089-1090.

${ }^{45}$ Dworkin, Religion, supra note 40, at 19.

${ }^{46}$ Martha Nussbaum, Upheavals of Thought: The Intelligence of Emotions, (Cambridge; New York: Cambridge University Press, 2001).

${ }^{47}$ See Rawls, Theory, supra note 2, at 42-44.

${ }^{48}$ It may even be possible to see a precedent for it in Hegel's Jena-period writings.

${ }^{49}$ Rawls, Theory, supra note 2, at 8 (stating: "I shall proceed by discussing principles which do apply to what is certainly a part of the basic structure as intuitively understood"), 159 ("The reasoning is informal and not a proof, and there is an appeal to intuition as the basis of the theory of justice").

${ }^{50}$ See ibid, § 9, "Some Remarks about Moral Theory", at 44 (arguing that "[i]n any case, it is obviously impossible to develop a substantive theory of justice founded solely on truths of logic and definition"); $§ 20$, "The Nature of the Argument for Conceptions of Justice", at 102-103 (stating that "[i]n order to do this [i.e. show[] ... that the two principles of justice are the solution for the problem of choice presented by the original position.], one must establish that, given the circumstances of the parties, and their knowledge, beliefs, and interests, an agreement on these principles is the best way for each person to secure his ends in view of the alternatives available"). A Theory of Justice contains multiple statements to the effect that its contractarian argument pre-supposes a conception of a democratic society as a fair system of co-operation among persons considerede as free and equal, and endowed with the twin moral faculties of having a sense of justice and a conception of the good.

${ }^{51}$ John Rawls, "Fairness to Goodness", (1975) 84 Philosophical Rev 536 at 546 (arguing that "the original position does not presuppose the doctrine of abstract individualism. This is defined as the doctrine that the fundamental aims and interests of individuals are determined independently from particular social forms; society and the state are
} 
these intuitions to be socially conditioned. As Chandran Kukathas and Philip Pettit well understood, "what is (and has always been) at issue for Rawls is 'background justice' in already existing societies." 52 Rawls was thus somehow concerned with "sociological moralism" or "ethical sociologism," some of his most fundamental claims being perpahs similar to that, defended by Axel Honneth, of a "moral integration of society" or a "normative social infrastructure."53 Rawls, however, stressed that there exist deep disagreements between the various articulated conceptions of justice integrated into the comprehensive doctrines. "Politically" detached from such doctrines by means of "the public reason," these conceptions of justice take their place on a horizon of a common background confusedly composed not only of values and intuitions, but also of "considered," albeit scattered and preanalytic, "judgments." For example, the strong plurality of the conceptions of justice within liberal societies does not prevent their members from being virtually unanimous in considering slavery or corruption to be injustices.

Yet if all societies, or at least those of a certain type, to which liberal democracies belong, possess a normative infrastructure whose interpretation is contested, is it surprising that in matters of Justice - that is to say "basic rights and duties" and "division of advantages" 54 or, in other words, "what we owe to each other" Rawls had done, in order to observe its most concrete manifestations? Is it surprising that people looked to constitutional law and justice for the most effective examples of the reflective equilibrium method? In other words, is it surprising that theories, such as the Dworkinian "law as integrity" and "moral reading of the constitution" philosophy, and practice of law — and in particular of constitutional law - as the method which Rawls had elaborated in order to put forward the contents of a public agreement on principles of justice, and which Dworkin renamed "interpretive equilibrium"? ${ }^{58}$ Dworkin speaks of "an

\footnotetext{
regarded as institutional arrangements that answer to these antecedent individual ends and purposes, as specified by a fixed and invariant human psychology. In contrast to this view, the theory of a well-ordered society stresses that the interests and ends of individuals depend upon existing institutions and the principles of justice they satisfy.") Rawls then refers to $\S 79$ of A Theory of Justice. His ethical sociologism, and in particular the grounding of his normative standpoint in a specific sort of society if not above all in the American society becomes more explicit beginning with the John Dewey Lectures of 1980 : « Le constructivisme kantien dans la théorie morale » (1980), trad. C. Audard, in Justice et démocratie, trad. C. Audard, P. de Lara, F. Piron et A. Tchoudnowsky, Seuil, 1993, p. 73-152.

${ }^{52}$ Chandran Kukathas and Philip Pettit, Rawls: A Theory of Justice and its Critics, (Stanford, CA: Stanford University Press, 1990) at 123.

${ }^{53}$ See especially St-Hilaire, Lutte, supra note 13, at 335-94; Maxime St-Hilaire, "Autour d'un paradigme juridique de la reconnaissance / Recognition as a Legal Paradigm?”, in Maxime St-Hilaire, ed, “Axel Honneth et le droit”, (2011) 78 Droit et société. Revue internationale de théorie du droit et de sociologie juridique 261.

${ }_{54}$ Rawls, Theory, supra note 2, at 113.

${ }_{55}$ TM Scanlon, What we owe to each other, (Cambridge, MA: Belknap Press, 1998).

${ }^{56}$ Dworkin, Empire, supra note 33.

${ }^{57}$ Ronald Dworkin, "The Moral Reading of the Constitution", New York Review of Books, March 21, 1996 [Dworkin, "Moral Reading”]; Ronald Dworkin, Freedom's Law: The Moral Reading of the American Constitution (Cambridge, MA: Harvard University Press, 1996).

${ }^{58}$ See Ronald Dworkin, "Rawls and the Law", in Ronald Dworkin, Justice in Robes (Cambridge, MA: Belknap Press, 2006) 241-261 [Dworkin, Robes]. See also Dworkin, Hedgehogs, supra note 33, at 63-66.
} 
accurate public conception of individual rights" ${ }^{29}$ and, in his second-to-last book and magnum opus, Justice for Hedgehogs, ends up presenting law as "a branch of morality." law itself - and not the theory of law alone ${ }^{61}$ - conceived as a specialized normative practice, belongs in his view to the realm of political morality, which is a branch of morality, which in turn is a branch of ethics, a vast component of the independent domain of value, to which his great work is devoted. Following Rawls, but more robustly, Dworkin, for whom the normative infrastructure or background justice consists of interpretive principles, ${ }^{62}$ recognizes the contribution of judicial review of legislation, and even that of law generally, to the development of a public conception of justice and to its implementation. ${ }^{63} \mathrm{He}$ even thinks that in the "original position," the partners would opt for his "interpretivist" conception of law, to which I will return. ${ }^{64}$ And while, for Rawls, a judge had in difficult cases to resort to "public reason," Dworkin rejects the restrictions that this concept imposes on the admissibility of arguments in the realms of politics and law. ${ }^{65}$ Finally, by becoming, in Dworkin's work, "interpretivism," the somewhat modified method of reflective equilibrium is, mutatis mutandis, extended, well beyond the area of application which Rawls attributed to it, to all the components of the independent domain of value, such as literature and art, as well as law, politics, morality, and ethics. ${ }^{66}$ Though "Rawls seemed himself, at least on some occasions, to have accepted a fully sceptical view",67 through a "constructivism" that may reads as straight political sociology, he "plainly had in mind, however, not a sociological but an interpretive search for overlapping consensus." 68

\footnotetext{
${ }^{59}$ Ronald Dworkin, "Political Judges and the Rule of Law", in Ronald Dworkin, A Matter of Principle (Cambridge, MA: Harvard University Press, 1985). 9 at 11-12 [Dworkin, "Political Judges"].

${ }^{60}$ Dworkin, Hedgehogs, supra note 33, at 5.

${ }^{61}$ See Jeremy Waldron, "Jurisprudence for Hedgehogs", NYU School of Law, Public Law Research Paper No. 1345, July 5, 2013, online <http://ssrn.com/abstract=2290309>.

${ }^{62}$ Dworkin, Hedgehogs, supra note 33, at 51 ("Interpretive concepts ... that we share in spite of disagreeing about which understanding of the concept is the best"); see also ibid, ch 8 .

${ }^{63}$ Dworkin, "Rawls and the Law", supra note 58, at 254-259.

${ }^{64}$ Ibid at 251 (arguing that "[t]hey might well think that they safeguard themselves better against arbitrairiness or discrimination if they do not instruct judges to do justice as they see it, but seek to discipline judges by insisting that they do their best to respect principled consistency as they see it.") However, in reality, Dworkin has stated that in looking for a reflective equilibrium, he did not find the specific thougt experiment of a Rawlsian original position fruitful. Building on game theory, he has, for his part, argued that the equality of rights is contingent on a minimum level of economic and social equality, which the Rawlsian simulation pre-supposes. As a result, it is by no means clear that a different conception would yield the same choice of an equality of rights over that of material welfare, or indeed that the gamble of inequality would not be attempted. On this point, see Ronald Dworkin, "The Original Position" in Norman Daniels (ed), Reading Rawls: Critical Studies on Rawls' Theory of Justice, (Standford, CA: Stanford University Press, 1989).

${ }^{65}$ Dworkin, "Rawls and the Law", supra note 58, at 254.

${ }^{66}$ See Arthur Ripstein, "Introduction: Anti-Archimedeanism" in Arthur Ripstein (ed), Ronald Dworkin (Cambridge, New York: Cambridge University Press, 2007) 1 at 8 (arguing that "Dworkin broadens the idea of reflective equilibrium to a more general account of interpretation, which is concerned with explaining how our judgements about various domains of value can be correct") [Ripstein, "Introduction"]. See also Dworkin, Hedgehogs, supra note 33, Part Two.

${ }^{67}$ Dworkin, Hedgehogs, supra note 33, at 65.

${ }^{68} \mathrm{Ibid}$, at 66.
} 
Dworkin is too frequently taken to be a natural lawyer. Notwithstanding his use of the word "morality" and his debate with H.L.A. Hart and the Hartians, ${ }^{69}$ his theory is neither a form of natural law nor one of philosophy as a formal source of law. ${ }^{70}$ Although he described himself as "anti-positivist," acknowledged the role of "moral judgment" in a jurist's work and, in that context admitted all sorts of arguments, he should be regarded as a thinker of second order legal positivity and of the normative (or "moral") significance of the Rule of Law. The Rule of Law, however, must then, with Waldron's significant assistance, be given back its universal character - although Waldron himself prefers to speak of "consensus."

\subsection{Second Order Legal Positivity}

To begin with, the "moral" principles enlisted by the Dworkinian conception of law are in no way absolutes. They have nothing to do with philosophical realism, but rather take root in a background justice incorporated in our social practices in the areas surrounding the idea of value. Dworkin is resolute in his non-foundationalism, his "anti-archimedeanism." ${ }^{71}$ As he acknowledges, this resolve is an adhesion or an inheritance, rather than a real contribution of his own. ${ }^{72}$ His conception of law thus seeks no support outside of the ordinary experience, which he calls "social practice" and examines from an internal point of view. Insofar as this practice is animated by an idea of value, to whose independent realm it belongs, he regards it as the locus, not of an agreement, but of interpretive debates. Besides shared convictions and considered judgments, a social practice in these areas includes specific modes of reasoning and of debating about principles and their implementation. And while, despite deep disagreements, not all interpretations are equally valid, it remains the case that the correctness of a given interpretation cannot be assessed otherwise than from an ordinary viewpoint, internal to the social practice in which it participates. According to Dworkin, the "moral principles of the law" thus belong to the realm of interpretation, which itself is located within a social practice. Since the practice in question is law, I will now consider how these "moral" principles are better understood as legal principles.

To be sure, Dworkin believes that the very limits of the various axiological social practices can be the subject of debate. ${ }^{73}$ Following Rawls, and in keeping with a traditional representation, he also locates law as a social practice within a larger framework, which he calls "political community." Law is thus situated downstream from the principles of this community, principles which he designates as "political morality." More precisely, it is within a "community of principle" - a model that he distinguishes both from a de facto community and a "rulebook

\footnotetext{
${ }^{69}$ Scott J Shapiro, "The 'Hart-Dworkin' Debate: A Short Guide for the Perplexed”, in Ripstein, Ronald Dworkin, ibid, 22.

${ }^{70}$ Ronald Dworkin, “'Natural' Law Revisited”, (1982) 34 U Florida L Rev 165-188.

71 "Give me a place to stand on, and I will move the Earth," Arichemedes reputedly said.

72 See Ronald Dworkin, "Objectivity and Truth: You'd Better Believe It" (1996) 25:2 Philosophy and Public Affairs 87 at 139.

${ }^{73}$ See Ripstein, "Introduction”, supra note 66, at 13.
} 
community" - that there exists, in Dworkin's view, a moral duty (albeit not an inconditional one) to obey the law. This duty flows not from a consensual acceptance of legal rules but from the fact of belonging to a common endeavour of a fair sharing of benefits and responsibilities, structured by a generalized adherence to the (meta)principle of "integrity," to which I will return below. ${ }^{74}$ In this way, the Dworkinian conception of law seems to enlist political-moral principles - not absolute principles, to be sure, but nonetheless principles external to law. Yet Waldron is right to go beyond this superficial impression:

It was very important for Dworkin that the invocation of principles in a case like [Riggs v. Palmer] should not be construed as a judge's reaching beyond the law for something purely moral. [...] Dworkin's position is that the discernment of a principle in a given body of law is not possible without the exercise of moral judgment. That does not mean the principle in question is nonlegal, that is, purely moral. ${ }^{75}$

We must thus be wary of accepting at face value Dworkin's claim that principles are a moral component of the law. Besides, the issue of their extra-legal character is not quite straightforward now that Dworkin regards law as a branch of morality. ${ }^{76}$ The target which Dworkin's legal philosophy attacked was precisely the "discretion" which Hartian positivists - Dworkin seems not to have been well acquainted with Hans Kelsen's work and the tradition within which it was situated - granted to judges in "hard cases" or, more generally, due to the "open texture" of the law. ${ }^{77}$ What most bothered Dworkin was the claim - meant to be descriptive but which, in Dworkin's view, based in interpretive social practice, had to be at least partly normative - that judges created law in a manner akin to that of a legislature. Seeing in this claim an injustice and a threat to the valuable practice of judicial review of legislation, he meant, at the same time, to respond to the Holmes Lectures which Judge Learned Hand, of the U.S. Court of Appeals for the Second Circuit, had given the year after Dworkin served as his law clerk. ${ }^{78}$

Dworkin himself summarizes his interpretivist conception of law as follows: "judges should enforce rules laid down by the legislature ..., but when confronted by a so-called gap, should not attempt to legislate as the legislator would, but should instead try to identify the principles of fairness or justice that best justify the law of the community as a whole and apply those principles to the new case." ${ }^{79}$ The right interpretation of the law applicable to a given case is that which is founded on a principled reconstruction which, at the level both of coherence and of our moral convictions, best justifies, as a whole, the system of positive law, which Dworkin calls "legal structure." In other words, this interpretation is that which achieves an exact "interpretive equilibrium between the legal structure as a whole and the general principles that are best

\footnotetext{
${ }^{74}$ See Dwrokin, Empire, supra note 33, at 202-224.

${ }^{75}$ Waldron, Laws Common, supra note 10, at 64.

${ }^{76}$ See notes 60-61, above, and accompanying text.

${ }^{77}$ HLA Hart, The Concept of Law, $2^{\text {nd }}$ ed (Oxford; New York: Oxford University Press, 1994) at 124-136.

${ }^{78}$ See Ripstein, "Introduction", supra note 66 at 4.

79 Dworkin, "Rawls and the Law", supra note 58, at 247-48.
} 
understood as justifying that structure. ${ }^{, 80}$ The true key to understanding Dworkin's contribution to legal thought, the intervention of the principles not only in the judge's, but also the lawyer's and the scholar's work, is the heart of his interpretivist (and thus at once descriptive and normative) model of the law as "integrity," which is nothing other than "the promise that law will be chosen, changed, developed, and interpreted in an overall principled way." ${ }^{, 11}$ The principles of Dworkin's model are derived from an interpretation of the "morality" of a "political community" - but interpretation by a judge or a jurist, and aiming at best justifying the system of positive law and ensuring its completeness. These principles thus present themselves as the meeting point between substantive political or moral justice and formal legal justice. It is a common mistake, however, to overemphasize the first of these two dimensions.

"Law as integrity" in fact mainly amounts to a broadening of the coherence requirement inherent in the equality principle which, in turn, structures the whole idea of law. Before speaking of the law's "integrity," Dworkin spoke of its "fairness" - more specifically, the "fairness of treating like cases alike," that is to say of formal justice. ${ }^{82}$ "Integrity" refers above of all to "the quality of being honest and having strong moral principles," and, secondarily, to "the state of being whole and not divided." ${ }^{83}$ Taking into account these two meanings, the move from "fairness" to "integrity" is suggestive: as it includes strong moral principles, the law is whole and complete.

Although, in the same way as a constitution - and notably that of the United States - can do explicitly, they refer to the background justice of a political community, these principles are essentially legal. With greater or lesser strength in different legal orders, one can object that, contrary to what Dworkin says, the substantive source of the principles is not the "morality" of a "political community," but legal doctrine. Yet it is always illusory to deny the fact that nonsuperficial and socially conditioned normative intuitions impact the work of the constitutional judge or lawyer. The essential legality of the Dworkinian principles resides elsewhere. The justification they supply is not only substantive. It is also, if not primarily, formal. Their interpretive reconstruction must, notably, make it possible to articulate coherently the all of the legislators', judges', and jurists' considered judgments, the entirety of the legal structure, the whole of the system of positive law.

Simply put, the Dworkinian conception of law takes a expansive view of the science of law, by broadening its understanding of that science's axiomatic coherence requirement. The interpretivist conception of law as integrity is ultimately that of legal science as a search for "coherence, not simply with particular doctrines here and there, but, as best as it can be achieved,

\footnotetext{
${ }^{80} \mathrm{Ibid}$, at 251.

${ }^{81}$ Dwrokin, Empire, supra note 33, at 214.

${ }^{82}$ Ronald Dworkin, "Hard Cases", in Ronald Dworkin, Taking Rights Seriously, (Cambridge, MA: Harvard University Press, 1977) 81 at 113 [Dworkin, Rights].

83 "Integrity", in Oxford English Dictionary .
} 
principled coherence with the whole structure of law." ${ }^{, 84}$ This is the point of the chain novel metaphor, ${ }^{85}$ as well as the allegory of judge Hercules. ${ }^{86}$ Thus the Dworkinian jurist "tries to impose order over doctrine," (the best order possible, and thus the right one), "not to discover order in the forces that created it. ${ }^{, 87}$ Much more than (extralegal or, so to say, pure) concepts of "liberty, equality, or democracy," that of "[1] egality is sensitive in its applications ... to the history and standing practices of the community ... because a community displays legality, among other requirements, by keeping faith in certain ways with the past." ${ }^{, 8}$ The law develops this supple culture of heritage, this flexible form of fidelity to the past by means of principles ascertained by jurists by implementing the legal metaprinciple of integrity. ${ }^{89}$

Dworkin was not the first to model the ascertainment of principles, which is a well-established practice of the science of law, and especially constitutional law. ${ }^{90}$ Indeed he has himself suggested that his model in no way departs from the traditional method of the common law. ${ }^{91}$ Within the continental European tradition, Adhémar Esmein had said, well before Dworkin, that as a branch of legal science, constitutional law "takes a state and a government that have reached a specific form, determined by custom or legislation, ... ascertains their spirit and fundamental principles, as well as the consequences of that spirit and principles, [and] thus constructs their logical and legal system. ${ }^{92}$ Principles such as "substantive due process of law" in U.S. law, the so-called "unwritten" constitutional principles in Canadian law, the "fundamental un-codified rights" and the "limits inherent in rights" in German law, the protection of some laws or provisions against "implied repeal" in U.K. law, the "constitutional implications" in Australian law, and perhaps even the "fundamental principles recognized by the laws of the republic in French law are so many examples of this second-order legal positivity.

Dworkin can indeed be criticized for having, against the run of his own interpretivism, "overpositivized" "moral principles" by insisting that constitutional provisions relative to fundamental

\footnotetext{
${ }^{84}$ Dworkin, "Rawls and the Law", supra note 58 at 250.

${ }^{85}$ See Dworkin, Empire, supra note 33 at 228-232.

${ }^{86}$ Ibid, chap 7 to 10 ; Dworkin, "Hard Cases", supra note 82.

${ }^{87}$ Dworkin, Empire, ibid, at 273.

${ }^{88}$ Ronald Dworkin, "Hart's Postscript and the Point of Political Philosophy", in Dworkin, Robes, supra note 58, at 183.

${ }^{89}$ See also Waldron, "Jurisprudence for Hedgehogs", supra note 61, at 25.

${ }^{90}$ In pre-Dworkinian American literature, see especially Roscoe Pound, “The Theory of Judicial Decision”, (1923) 36:6 Harv L Rev 641, 36:7 Harv L Rev 802, and 36:8 Harv L Rev 940.; Roscoe Pound, "The Ideal Element in American Judicial Decision", (1931) 45:1 Harv L Rev 136; Herbert Wechsler, "Toward Neutral Principles of Constitutional Law”, (1959) 73:1 Harv L Rev 1; Karl Llewellyn, The Common Law Tradition: Deciding Appeals, (Boston: Little, Brown, 1960). But the intellectual genealogy of the Dworkinian conception of law has been traced to the "first generation of English lawyers": Mark D Walters, "Legal Humanism and Law-as-Integrity", (2008) 67:2

Cambridge LJ 352.

${ }^{91}$ See Dworkin, Empire, supra note 33, at 276-312.

92 Adhémar Esmein, Éléments de droit constitutionnel, (L. Larose, 1896) at 21.
} 
rights referred to them. ${ }^{93} \mathrm{He}$ exaggerated the role of principles by suggesting that it is of them, rather than of positive norms, that the law consists. ${ }^{94} \mathrm{He}$ also deliberately blurred, if not ignored altogether, the distinction between substantive and formal sources of law - even though this distinction belongs to the ordinary experience of legal practice, the "social practice" which unites and characterizes jurists.

That said, in order to understand Dworkin's contribution clearly, we would do well not to overstate his self-declared anti-positivism. Dworkin offers neither merely another natural law critique nor yet a theory of moral philosophy as formal source of law, even though he does take the position that in appropriate cases, a judge is entitled to seek the lights of a philosopher's work. ${ }^{95}$ Rather, Dworkin's contribution ought to be understood as taking into account, thanks to an understanding of law as a specialized normative practice (as a normative science) rather than an object, ${ }^{96}$ something that in my opinion should be seen as a more abstract, more diffuse, and less "pure" level of legal positivity. But Dworkin's mistake was in failing to distinguish, in amalgamating the different levels of legal positivity. ${ }^{97}$ This is what made him lose the debate with the positivists on the issue of the system of formal sources of law. ${ }^{98}$ I believe, therefore, that an attempt, such as that made by Wil Waluchow, to subject the principles of "constitutional morality" to the Hartian rule of recognition is doomed to failure. ${ }^{99}$

While Dworkin rejects the theory of sources of law and amalgamates their different levels of positivity, for my part, I would suggest doing the exact opposite. We need to be able to distinguish the two levels of legal positivity, by maintaining, in accordance with the jurists' ordinary experience, the distinction between formal and substantive sources of law. The formal sources are legislation, ordinary or constitutional, and judicial decisions. ${ }^{100}$ Nor may the source

\footnotetext{
${ }^{93}$ See Dworkin, "Moral Reading", supra note 57, at 5 (arguing that "[a]ccording to the moral reading, these clauses must be understood in the way their language most naturally suggests: they refer to abstract moral principles and incorporate these by reference, as limits on government's power").

94 Ronald Dworkin, "The Model of Rules I" [Dworkin, "Model"], in Dworkin, Rights, supra note 82, 14.

${ }^{95}$ See Dworkin, "Rawls and the Law", supra note 58 at 254.

${ }^{96}$ See especially Jeremy Waldron, "Did Dworkin Ever Answer the Crits?", in Scott Hershovitz (ed), Exploring Law's Empire: The Jurisprudence of Ronald Dworkin (Oxford; New York: Oxford University Press) 155 at 161 (Arguing that "there are ... two ways of characterizing Dworkin's approach: (i) his earlier characterization in terms of norms called principles, i.e. norms that were comprised in the law just like rules - only in the background of the law rather than in the foreground; and (ii) his later approach which talked of rival theories put forward by those who were working with the existing law to justify a current decision").

${ }^{97}$ See, to the same effect, also ibid at 159 (claiming that Dworkinian law as integrity's "disadvantage is the way it assimilates principles and policies to more discrete forms of legal provision, such as statutory rules, as though the identification, individuation, and citation of the former were in the end not much different from the identification, individuation, and citation of the latter"). See also Joseph Raz, "Legal Principles and the Limits of Law" (1972) 81:5 Yale LJ 823 at 843

${ }^{98}$ See Shapiro, supra note 69, at 49-50.

${ }^{99}$ Wilfrid Waluchow, A Common Law Theory of Judicial Review: The Living Tree, (Cambridge; New York: Cambridge University Press, 2007) at 224 et seq.

${ }^{100}$ See Maxime St-Hilaire and Laurence Bich-Carrière, "La constitution juridique et politique du Canada: notions, sources et principes", in Stéphane Beaulac and Jean-François Gaudrault-Desbiens (eds), Droit constitutionnel, JurisClasseur Québec, looseleaf ed. (Montréal: LexisNexis Canada, 2011).
} 
be confused with its product. A principle can be the product of a formal source of law if it is codified in a constitutional text or established by case law. Otherwise, it can only be, as a matter of law, the product of a substantive source.

This makes it possible not to confuse a scholar and a judge, or a constitutional principle set out in an academic work and one recognized by the decisions of a constitutional court. Similarly, Matthias Jestaedt, for example, contrasts the concept of a legal "dual constitution", positive and meta-positive, to the integrationist eclecticism of German constitutional Dogmatik. It is not surprising that these critiques are equivalent, since in both cases, the issue concerns "fundamental questions regarding the relationship between legal science and positive law, [in other words] problems which must be considered in every legal culture." ${ }^{101}$ Dworkin, like Rawls, enlists all interpreted principles of background justice of a specific community, focusing on his own, the United States. This leads to the question of whether it is possible to move from national legal constitutional principles to global principles of constitutional law.

\subsection{From National Legal Principles to ius gentium}

In his famous 1986 book, Law's Empire, Dworkin wrote that "[i]ntegrity holds within political communities, not among them, so any opinion we have about the scope of the requirement of coherence makes assumptions about the size and character of these communities." 102 Almost two decades earlier, in an essay originally been published in the University of Chicago Law Review in 1967, "The Model of Rules I," he took the 1889 case of Riggs v. Palmer as the main foundation of his critique of legal positivism and his alternative principle-based conception fo the law. ${ }^{103}$ However, "Dworkin didn't address the transnational character of the principle appealed to in Riggs, and discussion of integrity was developed much later." ${ }^{104}$ This crucial observation belongs to Waldron. Let me quote him at greater length:

I suspect that if they notice it at all, most participants in the debate about Dworkinian principles read the passage [in Riggs] concerning "universal law administered in all civilized countries" as a natural law idea, picking up on the side of Dworkinian principles that refers to their moral appeal rather than their positive grounding. But that is wrong. [...] So there is this aspect of universal law as well as the Dworkinian logic of principles in Riggs v. Palmer. My aim is to bring the two aspects together, taking seriously the possibility that deep background principles, legal principles, may be inferred not just from a single existing body of positive law in the way Dworkin argued, but also from multiple legal systems taken together. Indeed, principles whose presence may not be so apparent in one system may come more clearly into view when we look at a whole array of legal systems ${ }^{105}$.

\footnotetext{
${ }^{101}$ Matthias Jestaedt, "La double constitution. Une stratégie positiviste”, (2011) 6 Jus Politicum. Revue internationale de droit politique, online $<$ http://www.juspoliticum.com/La-double-constitution-Une.html $>$.

${ }^{102}$ Dworkin, Empire, supra note 33, at 185-86.

${ }^{103}$ See Dworkin, "Model", supra note 94.

${ }^{104}$ Waldron, Laws Common, supra note 10, at 136.

${ }^{105} \mathrm{Ibid}$, at 66-67.
} 
As for what is to take up this intermediate space between the reality of positive law as a product of formal sources and the ideal realm of a philosophical natural law, Waldron prefers to speak not of "moral" prinicples specific to a political community, but of a ius gentium, in the sense of a set of principles specific to a legal-scientific community which by definition is global. From this follows another difference between Waldron and Dworkin, which might otherwise go unnoticed. In contrast to the Dworkinian national legal-political principles, the legal-scientific principles that Waldron epistemologizes are, in his view, the subject of a "consensus." This consensus is a general agreement, albeit non-unanimous and of course fallible, which reason requires us to take into account.

For while he agrees with Dworkin that, in natural as in moral sciences, interpersonal agreement is never a guarantee of truth, and that, conversely, the absence of agreement does not establish the absence of truth, Waldron has always accorded greater significance than Dworkin to the fact that, in the former realm, agreement is much more common than in the latter. ${ }^{106}$ Initially, Waldron had emphasized the fact that, while in the natural sciences there exist so to say more substantive modes of resolving disagreement, there is no equivalent that could structure one or several of the normative sciences. However, law supplied purely formal modes of resolving dsagreements. These were, in particular, the democratic procedures provided by electoral and parliamentary law. This is precisely why Waldron, contrary to Dworkin, took the position that the debate about metaphysical objectivity was clearly irrelevant to law alone, rather than to the entirety of the normative realm. ${ }^{107}$ This was also the crucial reason why Waldron opposed judicial review of the conformity of legislation to constitutional guarantees of rights and liberties, at least if it took the form of effective validity or applicability control (as opposed to a purely advisory procedure). ${ }^{108}$

This initial stage was before Waldron discovered ius gentium. ${ }^{109}$ Later on, he still denied that his opposition as a matter of principle to what he calls strong judicial review - an opposition which still wants to maintain - is at all incompatible with his plea that American courts engaged in such review resort to foreign law as ius gentium. ${ }^{110}$ Yet this denial is unconvincing. A reader of his 2012 book on the subject will find improbable his claim that a scientific legislator is ideal, and that constitutional adjudication resorting to ius gentium is merely a lesser evil. But, however

\footnotetext{
${ }^{106}$ Voir J. WALDRON, supra notes 34 et 96.

${ }^{107}$ Voir J. WALDRON, supra note 34, p. 170-171.

${ }^{108}$ See Jeremy Waldron, "The Core of the Case against Judicial Review", (2006) 115:6 Yale LJ 1346 [Waldron, “Core of the Case"]. See also Jeremy Waldron, “Judges as Moral Reasoners", (2009) 7:1 Int'1 J Const L 2.

${ }^{109}$ See Jeremy Waldron, "Foreign Law and the Modern ius gentium", (2005) 119:1 Harv L Rev 129 [Waldron, "Foreign Law"]; Jeremy Waldron, "Laws Partly Common to All Mankind (three lectures)", Storrs Lectures, Yale Law School, September 10-12, 2007, online, <http://www.law.yale.edu/news/5408.htm>; Waldron, Laws Common, supra note 10 . The stages which I distinguish here are "logical" rather than strictly chronological. The distinction I draw is not undermined by the mere fact that the central idea of the second stage was in fact sketched out just before the detailed presentation of some of the first stage's conclusions.

${ }^{110}$ See Waldron, Laws Common, supra note 10, at 143-51. This is Waldron's response to the objection of James Allan, a fierce opponent of the judicial review of legislation, who has declared himself "betrayed" by Waldron's defence of ius gentium : James Allan, “Jeremy Waldron and the Philosopher's Stone”, (2008) 45:1 San Diego L Rev 133.
} 
that may be, the important point here is that, contrary to Dworkin, Waldron acknowledges that agreement is significant. This is especially the case of scientific "consensus" which, although it by no means guarantees truth, nevertheless creates a presumption to that effect, and thus an obligation to take it into account. ${ }^{111}$ Waldron thus believes that, although a "right answer," a "just solution" can in theory exist notwithstanding profound disagreement, it remains the case that scientific consensus is the only post-metaphysical, non-realist substitute to the normative universal, to which reason attaches a duty of non-ignorance.

In his 2005 sketch, Waldron wrote that while "the law of nature posed itself explicitly as an ideal ... [i] us gentium ... afforded a more grounded focus of aspiration, looking not just to philosophic reason but what law had actually achieved in the world." ${ }^{112}$ One of the arguments which he then intuited was thus of a historical character: "[n]atural law might have provided the very basic premises of a normative account, but ius gentium embodied a set of enduring intermediate principles that one might use as touchstones for real-world legal systems." ${ }^{113}$ In his 2012 book, Waldron develops this historical argument, through which he distinguishes ius gentium, this "natural law" of the jurists, from the natural law of the philosophers.

Originally a despised branch of the pretorian law, the law of foreigners, the ius gentium was ultimately regarded by Roman jurists as an imperfect positivation of the Greek philosophical ideal of natural law. Later, in the work of Gaius, and even more strongly that of Ulpian, the distinction between ius gentium and natural law becomes less clear, only to be re-clarified in the work of Aquinas, where one can see a gap between the perspective of a reality of the natural law induced from common positive law and that of a natural law from which positive law ought to be deduced. During the Renaissance, ius gentium is associated, more or less confusely, with positive law, rather than a philosophical natural law. ${ }^{114}$ Later on, notably with the treaties of Osnabrück and Münster of 1648, that is to say the Peace of Westphalia, the ius gentium gives way to international law, as part of a lasting movement towards the positivization of law. A no less lasting consequence was a division between the positive law of the jurists and the natural law of the philosophers, which was so strong that the legal tradition of natural law was obliterated. Yet in contrast with the natural law of the philosophers,

[n]atural law jurisprudence never used to be a matter of individuals just inserting their own moral judgments into legal reasoning, any more than natural science was ever just a matter of idiosyncratic observations about energy or gravity. In both instances the goal was the accumulation of knowledge, not just the validation of individual intuitions. No one in the modern world would take seriously novel claims about energy or gravity that did not refer to the work of the scientific community at large. It is harder for us, however, to imagine something similar for our moral thinking about rights or justice, accustomed as we are to the privileges of the individual conscience. Yet this is exactly what ius gentium provided-the accumulated wisdom of the world on rights and justice. The knowledge is

\footnotetext{
${ }^{111}$ See Waldron, Laws Common, supra note 10, at 100-108.

112 Waldron, "Foreign Law", supra note 109, at 134.

113 Ibid.

${ }^{114}$ See Waldron, Laws Common, supra note 10, at 33-40.
} 
accumulated not from the musings of philosophers in their attics but from the decisions of judges and lawmakers grappling with real problems. And it was accumulated not only in the crude sense of one thing adding to another, but also in the sense of overlap, duplication, mutual elaboration, and the checking and rechecking of results that are characteristic of true science. Ius gentium, conceived in this way, is no guarantor of truth: a consensus in either the law or the natural sciences can be wrong. In neither field, however, is there a sensible alternative to paying attention to the established body of findings to which others have contributed over the years. ${ }^{115}$

Although one understands that Waldron intends to emphasize the differences between ius gentium and philsophy, it is somewhat misleading to describe the former as "a body of positive law." $" 116$ To be sure, in the same way as Dworkinian principles - whose logic is at work here ${ }^{117}$ - do not cease being mainly legal merely because their ascertainment involves, among other things, moral judgment, ${ }^{118}$ ius gentium does not become a form of moral or political philosophy just because "[i]t may alloy itself with elements of natural law inquiry." ${ }^{119}$ Nevertheless, Waldron's ius gentium does not correspond either to a national system of positive law or to an international or regional positive public law. ${ }^{120}$ Nor does it coincide with the entirety of foreign legal systems, or with all of them and supranational law together. It is rather "a sort of overlap" between these systems of positive law. ${ }^{121}$ Yet this indirect overlap defines ius gentium only partially and at a diffuse substantive level.

At a more formal level, ius gentium is meant to be distinct, separate, independent from these other systems whose legality, more positive, is of a different character than its own. ${ }^{122}$ Waldron says that ius gentium is a body of principles none of which "has the weight of a legal rule," or force of law or, in short, the authority of a norm of positive law. ${ }^{123}$ As a body, ius gentium is not a mere collection, but a "system" of principles. As it "is not really an institutionalized system of law[, a]ny systematicity it has must be static, in Kelsen's sense, that is, doctrinal or contentbased." ${ }^{24}$ However, Waldron's invocation of Kelsen's distinction between static and dynamic systematicity of law is mistaken. Kelsen's static systematicity of a legal system refers to the idea of a formal hierarchy between the categories of legal norms, not merely to the general idea of a systematicity of contents or, put differently, of coherent contents. ${ }^{125}$ Thus at a formal level, ius gentium differs from positive laws by its principle-based nature. It also differs from them at a

\footnotetext{
${ }^{115} \mathrm{Ibid}$, at 42 .

${ }^{116} \mathrm{Ibid}$, at 28 .

${ }^{117}$ See note 105 , above, and accompanying text.

${ }^{118}$ See note 75 , above, and accompanying text.

${ }^{119}$ Waldron, Laws Common, supra note 10, at 40 (Waldron adds that these "elements of natural law inquiry ... in their turn will reflect, in large part, a sense of what has happened down here among the nations of the earth").

${ }^{120}$ See $i b i d$, at $29-33$.

${ }^{121} \mathrm{Ibid}$, at 28.

${ }^{122}$ Voir idem, p. 74 : « [Ius gentim's] intimate relation with these systems is of course part of the reason for calling it law; my point is that there are also good systemic reasons for distinguishing it as a separate legal entity. »

${ }^{123}$ Idem, p. 208 : « No such principle has the weight of a legal rule. »

${ }^{124}$ Voir idem, p. $69:$ : [...] ius gentium is not really an institutionalized system of law. Any systematicity it has must be static, in Kelsen's sense, that is, doctrinal or content-based. »

${ }^{125}$ See Kelsen, supra note 14, chap 4.
} 
territorial level, by its diffused global reach. Substantively, however, it is closer to them, being situated at their more or less abstract intersection points. Waldron provides some examples of the principles of the ius gentium: no punishment without trial; an accused's right to be heard by an impartial tribunal and to summon witnesses; a general possibility of an enforced execution of contractual obligations; harsher treatment of intentional faults; differential treatment of minor citizens and those who are of age; a general possibility to dispose of the things of which one is the owner. ${ }^{126}$ Ius gentium is thus mostly public law, and indeed mainly constitutional law, and only rarely private law. ${ }^{127}$

It is important to keep in mind, however, that the principles of the jus gentium are the product of a legal science, the work of a global legal community understood as a scientific community. They are the subject of a legal-scientific consensus, and Waldron conceives this "consensus and [this] community" not only as "accumulation of authorities" but as a vast and "dense" methodological "network." ${ }^{28}$ Consequently, beyond substantive legal principles, "it is not so much empirical facts or moral insights or attractive reform proposals that jurists glean from other's judgments or from a worldwide legal consensus [as] ways of analyzing difficult problems - modes of specifically legal analysis which relate the elements of a problem to the basic reasons of justice and public welfare with which the law is concerned." ${ }^{\prime 29}$ Conceiving it not only as contents, but also as method, Waldron speaks of ius gentium as of a "repository of wisdom in the world from which it makes sense for us to learn," 130 rather than a "repository of principles," as others have described comparative law. ${ }^{131}$

Thus if Waldron's ius gentium is a "body of positive law," it is so only as a matter of what I call second-order positivity. As Waldron himself specifies, his ius gentium "is not an enacted body of law, but it is law nonetheless." 132 In his 2005 sketch, he represented it as "a source of normative insight grounded in the positive law of various countries and relevant to the solution of legal problems." ${ }^{133}$ In the more developed 2012 model, Waldron says that "[i]t is perhaps best understood as an additional common source of national law rather than as a distinct body of law in its own right, ${ }^{, 134}$ even though he then goes on to suggest the contrary. ${ }^{135}$ The contradiction is resolved once we understand, still more precisely, that ius gentium is neither a formal source of law, nor an immediate product of such a source, but a substantive source of law - a substantive global source of national as well as international law. As part of a second-order legality, it is

\footnotetext{
${ }^{126}$ See Waldron, Laws Common, supra note 10, at 5.

${ }^{127}$ See ibid, at 28.

${ }^{128} \mathrm{Ibid}$, at 105 . See also note 115 , above, and accompanying text.

${ }^{129} \mathrm{Ibid}$, at 99.

${ }^{130}$ Waldron, Laws Common, supra note 10, at 60.

${ }^{131}$ Alfred Cockrell, "Rainbow Jurisprudence", (1996) 12:1 South African J Human Rights, 1 at 27.

${ }^{132}$ Waldron, Laws Common, supra note 10, at 51.

${ }^{133}$ Waldron, "Foreign Law", supra note 109, at 143.

${ }^{134}$ Waldron, Laws Common, supra note 10, at 59.

${ }^{135}$ See also note 122 , above, and accompanying text.
} 
formally independent of the national, regional, and international systems of positive law, on which it is substantively dependent. Although Wadron rejects the expression, which he finds to be used ambiguously, ${ }^{136}$ as a global substantive source of law, his ius gentium can very well be described as a "persuasive authority," at least in Patrick Glenn's sense of an "authority which attracts adherence as opposed to obliging it." ${ }^{137}$ This tends to confirm the fact that Waldron's model of ius gentium has always been tied to a conception of law as reason rather than will. ${ }^{138}$ This distinction seems, indeed, to track that which Glenn makes between law as a national construction, which is hostile to the idea of foreign law as a "persuasive authority," and that of law as "alliance," which is favourable to it. According to Glenn, "[t]he nationalization of law has made it vulnerable. Its sources become too close, too particular, too subjective. In seeking to bind it fails to persuade and resistance becomes easier to justify than adherence." ${ }^{139}$ Besides, Waldron's 2012 book opens with, as an epigraph, the same quotation from the Institutes with which Glenn concluded his 1987 article: «Omnes populi, qui legibus et moribus reguntur, partim suo proprio, partim communi omnium hominum jure utuntur. »

The book, which Waldron dedicates to Dworkin, answers the question of the possibility of a passage from national constitutional legal principles to global constitutional legal principles in the affirmative, and with a positivity gain due to taking accordingly into account the constitutive consensus of the science of constitutional law. Waldron deserves a great deal of credit for overcoming the approximative and trivial forms of appeals to international and comparative law. But great though it is, his contribution remains, nonetheless, of an epistemological character. Beyond a few examples, and a more general claim that the idea of equal human dignity is so to say implicit in modern law, ${ }^{140}$ Waldron's work does not substantially present the system of global principles of constitutional law. Besides, although it conceives ius gentium not only as a contents but also as a method, its treatment of this subject remains evasive. In particular, it does not indicate how the science of constitutional law manages to move back and forth between often very general principles and the best practices which standards are supposed to be.

\section{METHODOLOGY}

The non-foundationalism of the current conditions of thought restores the irreducible part of faith that is implicit in any use of reason, including of course that which discovers a justice of secondorder legal positivity. Yet while agreement, as it does not abolish belief, cannot be a guarantee of truth, Waldron is right that scientific consensus is the object of a rational obligation of consideration. This is why, notwithstanding Waldron's (understandable) rejection of the term "universality," we can now reinterpret Nussbaum's claim that "universal ideas of the human do

\footnotetext{
${ }^{136}$ Waldron, Laws Common, supra note 10, at 21.

${ }^{137}$ H Patrick Glenn, "Persuasive Authority", (1987) 32:2 McGill LJ 261 at 263.

${ }^{138}$ See Waldron, "Foreign Law", supra note 109, at 146-47; Waldron, Laws Common, supra note 10 , at 108.

${ }^{139}$ Glenn, supra note 137, at 297.

${ }^{140}$ See Jeremy Waldron, "How Law Protects Dignity", (2012) 71:1 Cambridge LJ 200.
} 
arise within history and from human experience, and can ground themselves in experience."141 One of these ideas - the logically first principled specific expression of the value of equality within the legal-scientific "consensus" or, in other words, the meta-principle of legal science is the Rule of Law, Rechtsstaat, Etat de droit.

\subsection{Rule of Law}

The phrase has, in particular, been consecrated by the English version of the $3^{\text {rd }}$ recital of the Maastricht Treaty of 1992, the preamble of the Charter of Fundamental Rights of the European Union of 2000, the preamble and the article 2 of the Treaty of Lisbon of 2007, articles 2, 3, and 4 of the Interamerican Democatic Charter of 2001, the preamble of Canada's Constitution Act, 1982, paragraph 1(c) of the South African Constitution of 1996, and paragraph 1(a) of the U.K.'s Constitutional Reform Act 2005. Initially formal if not formalistic, the principle of the Rule of Law, in its modern version, is inextricably linked to that of the fundamental rights of the human person. These rights become meaningful in light of the principle of human dignity which following Waldron, even though he does not favour the substantive conception of the Rule of Law - must be thought of as a status, the highest status possible, but a universal status now, rather than one reserved, as it once was, to a caste, a class, or a rank. ${ }^{142}$ These two aspects - one formal, the other substantive - are linked to the institution of constitutional adjudication.

The phrase is modern: "Rule of Law" dates back to the 15th century; "Rechtsstaat" to 1798; "État de droit" to 1868 . The "discourse" is even more so. ${ }^{143}$ Yet at its highest level of generality, the idea which, as Lon Fuller summarized it, is that of "subjecting human conduct to the governance of rules," is an old one. ${ }^{144}$ To keep it at once very short and very simple indeed, the idea of quasi-intangible laws that must bind legislators themselves may be as old as that which underpinned the "laws of Solon." 145 Plato defends the idea of a government subject to "law" in Laws, as does Aristotle in the third book of Politics. Later, from the Magna Carta of $1215,{ }^{146}$ to Albert Venn Dicey's famous 1885 book, ${ }^{147}$ the progressive assertion of a principle of the control of legality of all actions, even those of heads of governments, by ordinary courts allowed the British legal tradition to contribute greatly to the effectiveness of an old ideal. Even before this

\footnotetext{
${ }^{141}$ See note 32 , above, and accompanying text.

142 See notably Jeremy Waldron, "Dignity and Rank", (2007) 48:2 Archives européennes de sociologie / European Journal of Sociology 201; Jeremy Waldron, Dignity, Rank, and Rights (Oxford; New York: Oxford University Press, 2012). For other interpetations of the principle of human dignity, see especially: Michael Rosen, Dignity: its History and Meaning, (Cambridge, MA: Havard University Press, 2012); George Kateb, Human Dignity (Cambridge, MA: Belknap Press, 2011); Oscar Schachter, “Human Dignity as as Normative Concept”, (1983) 77:4 Am J Int'1 L 848.

${ }^{143}$ Heuschling, supra note 4, at 19.

${ }^{144}$ Lon L Fuller, The Morality of Law (New Haven, CT: Yale University Press, 1964) at 106.

${ }^{145}$ See Martin Ostwald, From Popular Sovereignty to Sovereignty of Law: Law, Society and Politics in Fifth-century Athens (Berkeley, CA: University of California Press, 1986) at 497-524.

${ }^{146}$ On the Rule of Law's pre-theoretical manifestations, see especially Henry de Bracton, On the Laws and Customs of England, Samuel E Thorne, tansl, vol III (Cambridge, MA: Belknap Press, 1968) at 305-306.

${ }^{147}$ AV Dicey, Introduction to the Study of the Law of the Constitution, $10^{\text {th }}$ ed., (London: Macmillan, 1959).
} 
evolution had been completed, the Rule of Law made nothing short of an evolutionary leap in the United States. From the Virginia Declaration of Rights of $1776,{ }^{148}$ to the Federalist Papers of $1787-1788,{ }^{149}$ to Marbury v. Madison in $1803,{ }^{150}$ or, even before that, through American legal culture as a whole, dating back to the colonial period, ${ }^{151}$ a new nation had offered the world a new model of the Rule of Law, corresponding no longer to a legal, but a constitutional state. To this day, the modern concept of the Rule of Law refers notably to the idea of a written constitution which positivizes the fundamental rights of the human person, and that of a judicial review of constitutionality which extends to legislation. It has now been proven that, especially since the 1990s, the influence of the constitution ${ }^{152}$ and the constitutional case law $^{153}$ of the United States on the constitutional framers and judges of other nations is in a freefall, to the point that the improvement of the model is now led by more recent constitutional states, including Germany, South Africa and, according to a study by David Law and Mila Versteeg, Canada. ${ }^{154}$ However, contrary to federalism and presidentialism, judicial review is an element of the American constitutionalism whose influence is still growing. Their vast study thus gives Law and Versteeg the opportunity to note that "[i]t is perhaps ironic that the most popular innovation of American constitutionalism has been judicial review, given that this celebrated institution is nowhere mentioned in the U.S. Constitution itself." ${ }^{\prime 155}$ In 1946, 25\% of the world's written constitutions provided for some form of judicial review. In 2006, it was $82 \%$. Today it is close to $90 \% .^{156}$

The epistemological discussion of the first part of this article has borrowed much from Waldron. Yet he is still thought of as a fierce opponent of judicial review. In reality, he is only opposed to a very specific form of judicial review, which he calls the strong judicial review. It involves review (1) by courts, (2) on the basis of fundamental rights, of the constitutionality of (3) legislation;

\footnotetext{
${ }^{148}$ See especially Horst Dippel, "Modern Constitutionalism: An Introduction to a History in the Need of Writing", (2005) 73:1 Legal Hist Rev 153.

${ }^{149}$ Alexander Hamilton, "No. LXXVIII" in James Madison, Alexander Hamilton, \& John Jay, The Federalist on the New Constitution (District of Columbia: Hallowell, 1831) 384 at 386 (explaining that "[b]y a limited Constitution, I understand one which contains certain specified exceptions to the legislative authority ... Limitations of this kind can be preserved in practice no other way than through the medium of courts of justice, whose duty it must be to declare all acts contrary to the manifest tenor of the Constitution void. Without this, all the reservations of particular rights or privileges would amount to nothing").

${ }^{150}$ Marbury v Madison, (1803) 5 US (1 Cranch) 137 (1803).

${ }^{151}$ See Gordon S Wood, "The Origins of Judicial Review", (1988) 22:4 Suffolk UL Rev 1293.See also Alison L LaCroix, The Ideological Origins of American Federalism, (Cambridge, MA: Harvard University Press, 2010) at $139-145$.

${ }^{152}$ See David S Law and Mila Versteeg, "The Decline of the United States Constitution", (2012) 87:3 NYU L Rev 762.

${ }^{153}$ Voir Heinz Klug, "Model and Anti-Model: The United States Constitution and the "Rise of World Constitutionalism"”, 2000:3 Wisconsin L Rev 597; Bruce Ackerman, "The Rise of World Constitutionalism", Occasional Papers, Yale Law School Legal Scholarship Repository, Paper 4, 1996.

${ }^{154}$ See Law and Versteeg, supra note 152, at 809-23.

${ }^{155} \mathrm{Ibid}$, at 793.

${ }^{156}$ See $i b i d$, at 766 and 793.
} 
specifically, of (4) the validity or applicability of legislation. ${ }^{157}$ In a recent text, Waldron distinguishes judicial review and judicial supremacy, acknowledging that even if strong, the former, which at its best may merely amount to a modest review power, does not involve the latter, which alone is what truly disturbs him now. ${ }^{158} \mathrm{He}$ admits that not only his personal opposition to a form of judicial review is a minority viewpoint, ${ }^{159}$ but also that Mark Tushnet's wish, a withdrawal of the constitutions from the custody of the judicial power, will not come true. ${ }^{160}$ Besides, in 2011, Waldron had taken the position that the Rule of Law neither excluded nor entailed judicial review, towards which it rather is "neutral." ${ }^{161}$ There is also, as we have seen, a tension in Waldron's work between a conception of law as a science or body of technical knowledge, and the claim that legislators, for example, could conduct a constitutional review of a legal nature.

The universal ambit of the principle of human rights - positivized by most written constitutions, of which the overwhelming majority provides for some form or other of judicial review - is first of all suggested by the Universal Declaration of 1948. It is also suggested by the two international covenants of 1966, the one dealing with civil and political rights, and the other with economic, social, or cultural rights. So it is by the Final Act of Helsinki of August 1, 1975, which closed the Conference on the Security and Co-operation in Europe. Recall, by the way, that it was still the position of the Union of the Soviet Socialist Republics (USSR) during the Conference of 1973-75 — which in 1995 became the Organization for the Security and co-operation in Europe (OSCE) - that human rights were conceivable without democracy. Yet although multiparty democracy did not expressly appear in the work of this forum - which aims at the adoption of non-legally binding instruments whose interpretive authority has nonetheless been demonstrated - until the Bonn conference of 1990 on economic co-operation in Europe, this position quickly proved unsustainable. Already the Final Act of 1975 officialized the recognition by the two superpowers of the day, by European states, and by Canada of the right of peoples to selfdetermination. The Madrid meeting of 1980-83 saw the adoption of the objective of the promotion of the participation of persons in political life. In Vienna, in 1986-89, the member states agreed that political rights were among those of the highest importance, and the states which had not already done so undertook to adhere to the two international human rights covenants, one of which notably protects political rights. Beyond the economic discourse, the role of this legal dialectic in the collapse of the Soviet empire and model remains largely underappreciated. Finally, to come back to the general universality of human rights, let us recall that, on June 25, 1993, notwithstanding lively debates, the 171 nations taking part in the World

\footnotetext{
${ }^{157}$ See Waldron, "Core of the Case", supra note 108.

158 Jeremy Waldron, "Judicial Review and Judicial Supremacy”, NYU School of Law, Public Law Research Paper No. 14-57, October 2, 2014, online: $<$ http://ssrn.com/abstract=2510550>, at 5.

${ }^{159}$ Ibid, at 4.

${ }^{160}$ Ibid, at 33; Mark V Tushnet, Taking the Constitution Away from the Courts (Princeton, NJ: Princeton University Press, 1999).

${ }^{161}$ Jeremy Waldron, "The Rule of Law and the Importance of Procedure", in James E Fleming, ed, Nomos 50: Getting to the Rule of Law, (New York: New York University Press, 2011) 1 at 24 [Waldron, "Procedure"].
} 
Conference on Human Rights agreed on the Vienna Declaration and Programme of Action, which notably stipulates, in its Article 5, that "[a]11 human rights are universal, indivisible and interdependent and interrelated," and that "[w]hile the significance of national and regional particularities and various historical, cultural and religious backgrounds must be borne in mind, it is the duty of States, regardless of their political, economic and cultural systems, to promote and protect all human rights and fundamental freedoms." In 2006, even as he devoted a lengthy article to his opposition to strong judicial review, Waldron also took note of a "worldwide consensus on human rights," as well as a "history of thinking about rights." ${ }^{162}$ In his 2012 book on ius gentium, he made the following clarification, which also extends Nussbaum's statement to the effect that the universal can very well rest on human experience:

Neither modern human rights law nor national bills of rights came into existence by magic. Historians trace the two ideas to the activity of certain elites: philosophers and statesmen at end of the eighteenth century and a small group of influential statesmen and diplomats in the decades following the Second World War. Elites were certainly the immediate sponsors of these ideas. But there is a broader sense in which the emergence of individual rights guaranteed by law was the product of a popular movement among the rights bearers themselves. The people themselves-the peoples themselves-indicated that they were no longer willing to be ruled without these guarantees. It was not the rulers of the world, but the people of the world who insisted on this arrangement, though the rulers did respond affirmatively and more or less enthusiastically to their demands. ${ }^{163}$

It is true that the idea of a European constitutional ius commune is reflected in European human rights law, as well as in EU law. The preamble of the Convention for the Protection of Human Rights and Fundamental Freedoms (the European Convention on Human Rights, or the ECHR) refers to a "a common heritage of political traditions, ideals, freedom and the rule of law." For its part, in the Internationale Handelsgesellschaft and Nold decisions, respectively in 1970 and 1974, the Court of Justice of the European Communities spoke of "the constitutional traditions common to member states," referring, in both cases, to fundamental rights. This notion of "constitutional traditions common to the Member States" was then included in article 6, paragraph 3 of the Maastricht Treaty of 1992. In 2007, the Lisbon treaty endowed the European Union with a Charter of Fundamental Rights. The idea of a European constitutional "law" or "heritage" is used by authors such as Peter Häberle ${ }^{164}$, Rainer Arnold, ${ }^{165}$ and Dominique Rousseau. ${ }^{166}$ Yet as Marie-Claire Ponthoreau points out "these common constitutional principles are not specifically European, being the heritage of a long legal and political tradition shared with

\footnotetext{
162 Waldron, "The Core of the Case", supra note 108, at 1365.

${ }^{163}$ Waldron, Laws Common, supra note 10, at 133.

${ }^{164}$ Peter Häberle, L'État constitutionnel, Constance Grewe, ed; Marielle Roffi, transl, (Aix-en-Provence: Presses universitaires d'Aix-Marseille; Paris: Economica, 2004).

${ }^{165}$ Rainer Arnold, "European constitutional law: some reflections on a concept that emerged in the second half of the 20th century", (1999) 14 Tul Eur \& Civ L Forum, 49.

${ }^{166}$ Dominique Rousseau "La notion de patrimoine constitutionnel européen", in Droit et politique à la croisée des cultures. Mélanges en l'honneur de Philippe Ardant, (LGDJ, 1999) 27.
} 
the Americans," ${ }^{167}$ who, I am tempted to remind the reader, have had their share of influence on the drafting of the Grundgesetz of $1949 .{ }^{168}$

The Rule of Law, human rights, and democracy are often presented as the three great principles of the global constitutional heritage. However, a coherent reconstruction makes it possible to situate them as aspects of a modern democratic Rule of Law state founded on human rights. To begin with, modern representative democracy can be "derived" ${ }^{169}$ from human rights (in particular the political rights and the civil liberties of thought, opinion and expression), which are protected by most written constitutions. ${ }^{170}$ These rights then add a substantive component ${ }^{171}$ to the formal concept of the Rule of Law, ${ }^{172}$ which, by expanding from a control of legality to that of constitutionality, in turn reinforces their own positivity. It is thus possible to speak, more concisely, of a modern conception of the Rule of Law.

According to Brian Tamanaha, a written constitution, democratic elections, explicitly protected individual rights, the "separation of powers" - though it would be preferable to speak of the narrower principle of judicial independence ${ }^{173}$ - and judicial review of the constitutionality of legislation are now considered to be essential to liberalism and to the Rule of Law. ${ }^{174}$ Although it retains a formal dimension, this modern conception of the Rule of Law is sometimes described, by way of a pars pro toto syndecdoche, as the "substantive conception," 175 especially since it is true that it gives rights the pride of place. These rights become "fundamental" in that they limit the action of the state all the more for being now its foundation and investing it with an implementing mission. This is why Dworkin, who unreservedly adheres to this modern conception of the Rule of Law despite his apparent parochialism, is right to call it the "rights conception." ${ }^{.176}$

For his part, Waldron, to whom I have largely been referring here, does not share this substantive conception of the Rule of Law. ${ }^{177}$ More even than a formal conception, he favours yet another,

\footnotetext{
${ }^{167}$ Marie-Claire Ponthoreau, Droit(s) constitutionnel(s) comparé(s), (Paris: Economica, 2010) at 30.

${ }^{168}$ See Donald P Kommers and Russel A Miller, The Constitutional Jurisprudence of the Federal Republic of Germany, 3rd ed, rev and expanded, (Durham, NC: Duke University Press, 2012) at 3-8.

${ }^{169} \mathrm{I}$ am not using this term in a foundational sene, according to which democracy would only exist because of human rights, but in the interpretive one, meaning that it is human rights that best justify democracy.

${ }_{170}^{170}$ Law and Versteeg, supra note 152, at 770-79.

${ }^{171}$ TH Bingham, The Rule of Law, (London; New York: Allen Lane, 2010) at 33 (asserting that "the rule of law now demands protection of fundamental human rights").

${ }^{172}$ See Otto Bähr, Der Rechtsstaat. Eine publicistische Skizze, (Cassell; Göttingen: Wigand, 1864); Rudolf von Gneist, Der Rechtsstaat, (Berlin: Julius Springer, 1872); Dicey, supra note 147; EP Thompson, Whigs and Hunters: The Origins of the Black Act, (London: Allen Lane, 1975); Fuller, supra note 144.

${ }^{173}$ Hans Kelsen, La démocratie : sa nature, sa valeur, $2^{\text {nd }}$ ed, C Eisenmann, transl, (Paris: Dalloz, 2004).

${ }^{174}$ See Brian Z Tamanaha, On the Rule of Law: History, Politics, Theory (New York; Cambridge: Cambridge Univeristy Press, 2004) 55.

${ }^{175}$ See especially P Craig, "Formal and Substantive Conceptions of the Rule of Law: An Analytical Framework", 1997 Public Law 467.

${ }^{176}$ See especially Dworkin, "Political Judges", supra note 59.

${ }^{177}$ See especially Jeremy Waldron, “The Concept and the Rule of Law”, (2008) 43:1 Ga L Rev 1.
} 
procedural one. ${ }^{178}$ He thus wonders why the crucial role of procedural principles and standards is missing from the formalist theories of the Rule of Law, the procedural dimension of law being in his view irreducible to its formal dimension, with which it sometimes is even in tension. As he does not adhere to the substantive conception, Waldron does not seriously explore the possibility of reconstructing fundamental rights as procedural guarantees (not only judicial, but also administrative, legislative, and constitutional). It seems to me that, although it is most interesting, the procedural conception of the Rule of Law should not be situated on the same level as the opposition between the formal and substantive conceptions, which it rather seeks to transcend. That said, as part of the development of his work, Waldron, without ever renouncing his views, has been led increasingly to present his opposition to the substantive conception of the Rule of Law as a personal preference, rather than a necessary consequence of his theoretical claims. ${ }^{179}$

The global principles of constitutional law can thus be reduced to a modern conception of the Rule of Law focused on fundamental rights. Thus goes the synthesis. At the level of analysis, T.R.S. Allan - who, incidentally, argues that judicial review can very well make do without a written constitution ${ }^{180}$ — points out, quite rightly, that "[ $\left.t\right]$ he rule of law is an amalgam of standards, expectations, and aspirations." 181 Indeed, it is necessary to address the question of what it is that distinguishes a standard from a principle, an indicator, or a simple horizon.

\subsection{From Principles to Standards}

According the Rule of Law Index of the World Justice Project, for example, the Rule of Law today comprises: "(1) Constraints on government powers; (2) absence of corruption; (3) open government; (4) fundamental rights; (5) order and security; (6) regulatory enforcement; (7) civil justice; (8) criminal justice; (9) informal justice. ${ }^{182}$ The organization publishes an annual report assessing the quality of the Rule of Law in a growing number of countries on the basis of these criteria. But these criteria, from which is derived, for example, that of access to justice, are not standards. Nor are what the Venice Commission considers to be the sujects of a consensus on the essential components of the Rule of Law: "(1) [1] egality ... (2) [1] egal certainty; (3) [p]rohibition of arbitrariness; (4) [a]ccess to justice before independent and impartial courts, ... (5) [r] espect for human rights; (6) [n]on-discrimination and equality before the law. "183 Both of these are lists

\footnotetext{
${ }^{178}$ See especially Waldron, "Procedure", supra note 161.

${ }^{179}$ See ibid, at 4 (stating: "I am not as hostile as I once was to a substantive conception of this ideal").

${ }^{180}$ TRS Allan, Constitutional Justice: A Liberal Theory of the Rule of Law, (Oxford; New York: Oxford University Press, 2003); TRS Allan, "In Defence of the Common Law Constitution: Unwritten Rights as Fundamental Law", (2009) 22:1 Can JL \& Jurisprudence 187.

${ }^{181}$ TRS Allan, Law, Liberty, and Justice: The Legal Foundations of British Constitutionalism, (Oxford: Clarendon Press; New York: Oxford University Press 1993) at 21.

182 The World Justice Project, WJP Rule of Law Index 2014, online: < http://worldjusticeproject.org/rule-of-lawindex $>$.

${ }^{183}$ European Commission for democracy through law (Venice Commission), Report on the rule of law, CDL$\mathrm{AD}(2011) 003 \mathrm{rev}$, para 41, online : < http://www.venice.coe.int/webforms/documents/?pdf=CDL-AD(2011)003reve>. para 41 [Venice Commission, Rule of Law].
} 
of principles structuring the modern Rule of Law or of indicators which can be inferred from such principles. The same is true, for example, of the Raoul Wallenberg Institute's "Guide for Politicians." ${ }^{184}$ As for the World Bank's Worldwide Gouvernance Indicators (WGI), they, like other approaches that make the Rule of Law contingent on an economic conception of development, emphasize its formal dimension, especially the effectiveness requirement, which becomes a measure of "efficiency," especially that of the protection of property rights, measured most often by the perceptions of the actors. ${ }^{185}$ David Restrepo Amariles concludes that the Rule of Law is not an end in itself on such views, but a mere means. ${ }^{186}$ A somewhat different way of seeing the World Bank's indicators leads me to the conclusion that the Rule of Law does not appear there as a metaprinciple of ius gentium as science of constitutional law, but as something which the science of development economics borrowed from the science of law and more or less repurposed for its own ends.

While the principle or the indicator, such as the indepedence of the judiciary or of the constitutional judges, can be merely the result of an analysis, of the application of a derivative legal logic ${ }^{187}$ to the product of the generally consensual interpretive reconstruction of the global practice of the Rule of Law, a standard is, for its part, more directly a practice itself or, as we shall see, a category of practices regarded as being among the best. The search for best practices can include a negative or eliminatory aspect, an ascertainment of the worst cases, of what Kim Scheppele describes as "aversive precedents." ${ }^{188}$ Standards are different from principles or indicators by their greater degree of concreteness, of positivity, of precision. Speaking of the subindicators of the World Bank's Rule of Law indicator, Restrepo Amariles notes that 'the subindicators of the Rule of Law are too broad, and include too many agregated factors, which makes it difficult to identify the provisions or procedures that ought to be reformed. ${ }^{189}$ On the one hand, this is also generally true of the "factors" and the "sub-factors" of the indexes exclusively devoted to the Rule of Law. On the other, this is normal, as the function of principles, indicators, and factors is not the same as that of standards, which is complementary to theirs. To be sure, the standards are valued over and above other practices in accordance with principles and their

\footnotetext{
${ }^{184}$ Raoul Wallenberg Institute of Human Rights and Humanitarian Law / The Hague Institute for the Internationalisation of Law, Rule of Law: A guide for politicians, 2012, online $<$ http://rwi.lu.se/what-wedo/academic-activities/pub/rule-of-law-a-guide-for-politicians/>.

${ }^{185}$ See, The World Bank Group, The Worldwide Governance Indicators, 2013, online: $<$ http://info.worldbank.org/governance/wgi/index.aspx\#home>; Daniel Kaufmann, Aart Kraay and Massimo Mastruzzi, « The Worldwide Governance Indicators: Methodology and Analytical Issues », September 2010, World Bank Policy Research Working Paper No. 5430, online: $<$ http://papers.ssrn.com/sol3/papers.cfm?abstract $\mathrm{id}=1682130>$

${ }^{186}$ David Restrepo Amariles, "The mathematical turn: l'indicateur Rule of Law dans la politique de développement de la Banque Mondiale", in Benoît Frydman and Arnaud Van Waeyenberge (eds), Gouverner par les standards : de Hume aux rankings, (Brussels: Bruylant, 2014) 193 at 193, 231.

${ }^{187}$ See note 169 , above.

${ }^{188}$ Kim Lane Scheppele, “Aspirational and Aversive Constitutionalism: The Case for Studying Cross-Constitutional Influence through Negative Models", (2003) 1:2 Int'l J Const L 296.

${ }^{189}$ Restrepo Amariles, supra note 186, at 233. See also Kenneth E Davis, "What can the Rule of Law Variable tell us about the Rule of Law?", (2004) 26:1 Mich J Int'1 L 141.
} 
derivatives. Moreover, the distinction between an abstract principle or sub-principle and a concrete standard will not always be easy to draw in practice. Yet it remains the case that in order to ascertain a standard, it is certainly necessary to deploy a principled reconstruction, but in order to make an evaluative return to the practice, at a larger scale, that is to say, in greater detail than needed when formulating indicators or factors. Lastly, contrary to principles or indicators which only enable a relative consistency control, a standard must normally be capable of grounding an absolute conformity control.

The requirement of "a transparent, accountable and democratic process for enacting law" 190 is doubtless more of an indicator. That granting dual voting rights to national minorities "can only be justified if [1] it is impossible to reach the aim pursued through other less restrictive measures which do not infringe upon equal voting rights; [2] it has a transitional character; [and 3] it concerns only a small minority" 191 is closer to a standard. The same can be said of the idea that, as "federal states in Europe and elsewhere in the world all have bicameral systems [because p]opular representation has to be accompanied by representation of the constituent geographical entities ... this situation ... has become a key rule of federalism." ${ }^{192}$ Finally, to argue that the "[t]he permissible departure from the norm" of equality of the electoral weight of constituencies "should not be more than 10\%, and should certainly not exceed $15 \%$ except in special circumstances" such as the need to "protect[] ... a concentrated minority," or to ensure the representation of a "sparsely populated administrative entity" 193 is, assuredly, to invoke a standard. So is it to claim that, when it exists, "public financing [of political parties] must be aimed at each party represented in Parliament." 194 Lastly, numerous elements of the Venice Commission's reports on judicial appointments are standards as well. ${ }^{195}$ Now, while the arsenal of principles which make up the modern conception of the Rule of Law takes the role of a value criterion in an effort of ascertainment of the best practices of constitutional law throughout the world, it is not alone in doing so. It is not all there is to the standard-setting method.

\subsection{Comparative Law, the Search for Functional Equivalents, and Typology}

\footnotetext{
${ }^{190}$ Venice Commission, Rule of Law, supra note 183, at para 41.

${ }^{191}$ European Commission for democracy through law (Venice Commission), Dual voting for persons belonging to national minorities, CDL-AD(2008)013, at para 72, online: $<$ http://www.venice.coe.int/webforms/documents/CDL$\operatorname{AD}(2008) 013 . a s p x>$ [Venice Commission, "Dual Voting"].

${ }^{192}$ European Commission for democracy through law (Venice Commission), Report on Second Chambers in Europe: "Parliamentary Complexity or Democratic Necessity", prepared by Patrice Gélard, CDL(2006)059rev, at para 32, online: < http://www.venice.coe.int/webforms/documents/CDL(2006)059rev.aspx>.

${ }^{193}$ European Commission for democracy through law (Venice Commission), Code of Good Practice in Electoral Matters: Guidelines and Explanatory Report, CDL-AD (2002) 23 rev, at para 15, online: < http://www.venice.coe.int/webforms/documents/CDL-AD(2002)023rev.aspx > [Venice Commission, Electoral Matters].

${ }^{194}$ European Commission for democracy through law (Venice Commission), Code of Good Practice in the Field of Political Parties and Explanatory Report, CDL-AD(2009)021, at para 164 [Venice Commission, Political Parties].

${ }^{195}$ European Commission for democracy through law (Venice Commission), Judicial Appointments, CDL$\mathrm{AD}$ (2007)028, online: <http://www.venice.coe.int/webforms/documents/CDL-AD(2007)028.aspx > [Venice Commission, Judicial Appointments].
} 
To value some effective practices of constitutional law above others that exist in the world, and so to make them into standards, already implies resorting to some extent to comparative constitutional law. That this is done in light of principles already suggests that positive international public law will not be the only point of comparison. For example, in 1999, Sujit Choudhry doubtless made a contribution to the debate by insisting on taking better account of the fact that the world's supreme and constitutional courts often refer to "comparative sources" that "are not necessarily part of international law." 196 According to Ponthoreau, "questions of methodology have seldom been considered in comparative constitutional law," as they have been by private law comparativists. ${ }^{197}$ But the disagreement between comparativists, including on the topic of "methodology," which is supposed to bring them together, is rather more general, and has indeed been described as an "identity crisis." ${ }^{198} \mathrm{We}$ have seen that, as a matter of epistemology, the Waldronian ius gentium model went beyond vague invitations to resort more to international law as well as to comparative law, even as it remained embryonic at the level of methodology. But while ius gentium is irreducible to the sum of national, regional, and international systems of positive law, its scientifically consensual development nevertheless involves taking account of these systems, in which it is substantively anchored. It must thus be methodologically situated, if not among, then in relation to the main current approaches to comparative law. From this perspective, the ius gentium model seems to tend towards so-called normative or universalist approaches, which its development could no doubt reinvigorate. This notably means that it belongs methodologically to a category of functionalist approaches and that it disclaims the form of contextualism that presents itself as a categorical or otherwise strong objection to comparison.

Legal scholarship is still weighed down by sterile and boring debates regarding the very possibility of legal comparison. This is a symptom of a generalized epistemological and, therefore, methodological malaise. Of course, comparativists must attempt to take stock of system, of culture, of language, and of the other components of "context." Of course, they ought to be prudent in the matter of transplants, ${ }^{199}$ even while locating them within an inevitable process of acculturation. The law, as any science, is not without its difficulties. But there is nothing there that ought to be held up as an insuperable obstacle. And yet, under the more or less conscious influence of two apparently contradictory but really convergent lines of thought, namely empirical scientism and postmodernism, this is how legal contextualism sees the matter. All of its manifestations are located on a sort of continuum that ranges from a culturalism that

\footnotetext{
${ }^{196}$ Choudhry, supra note 9 , at 828.

${ }^{197}$ Ponthoreau, supra note 167 , at 50.

${ }^{198}$ Choudhry, supra note 9, at 829 (arguing that "[b] eyond ... broad generalities, however, comparative law scholars differ sharply on the aims and purposes of their discipline"). » See also Mary Ann Glendon, Paolo G Carozza, Colin B Picker, Comparative Legal Traditions: Text, Materials and Cases on Western Law, $3^{\text {rd }}$ ed, (St Paul, MN: Thomson/West, 2007).

${ }^{199}$ Alan Watson, Legal Transplants: An Approach to Comparative Law, (Edinburgh: Scottish Academic Press, 1974).
} 
purports to belong to social or historical sciences on one extreme, to a neoexistentialism on the other, with a whole spectrum of identitarianisms in the middle. Waldron would like to believe that such ideas, which were briefly successful during the Romantic age due, for example, to Herder and Savigny work, belong to the past of legal science. ${ }^{200}$ And yet, a contextualism that asserts the impossibility of a normatively fruitful comparison and of the discovery of equivalents can be found, to give but a few examples, in the work of a William Alford, ${ }^{201}$ a George Fletcher, ${ }^{202}$ or a Pierre Legrand, who even proclaims the absolute singularity of any legal system properly understood as a "culture.",203

A somewhat more sophisticated form of contextualism is obviously influenced by the work of philosophers who are at once "communitarian" and "post-colonial," such as Charles Taylor ${ }^{204}$ and James Tully. ${ }^{205}$ It insists on an intercultural legal "dialogue," a legal "interculturalism.", 206 This culturalist form of contextualism can be seen, for example, in the work of Sarah Harding ${ }^{207}$ and Sujit Choudhry. ${ }^{208}$ This approach aims at transcending the opposition between particularism and universalism - but fails to do so. First, it is mistaken as to the nature of the current forms of universalism, by committing precisely the error which, relying on Nussbaum, I described above, and which consists in regarding it as a necessarily metaphysical foundationalism. ${ }^{209}$ Choudhry is quite simply wrong to assert that universalist approaches to comparative law are "premised on extremely strong normative claims," and involve a legal science "that is openly normative in character," in the sense that this science is purely philosophical and that the global principles and standards these claims rehabilitate are (philosophically) "transcendent." ${ }^{210} \mathrm{He}$ is no closer to truth when he asserts that "dialogical interpretation" is more legitimate than any universalism. ${ }^{211}$ Secondly, postmetaphysical universalism involves overlapping principles, and admits of a reasonable diversity of implementations, so that, accepting a measure of particularity, universalist approaches to law have long renounced the project of a general uniformization of positive law,

\footnotetext{
${ }^{200}$ See Waldron, Laws Common, supra note 10, at 5 (suggesting that "jurisprudence has left behind the doctrine, which flourished briefly in the nineteenth century, that legal ideas were the outgrowth of the national character of particular peoples and, like their culture and their language, were distinctive, unique, and valuable in their peculiarity").

${ }^{201}$ William P Alford “On the Limits of 'Grand Theory' in Comparative Law”, (1986) 61:3 Wash L Rev 945.

${ }^{202}$ George P Fletcher, "The Universal and the Particular in Legal Discourse”, 1987:2 Brigham Young UL Rev 335; GP Fletcher, "Constitutional Identity”, (1993) 14:(3-4) Cardozo L Rev 737; GP Fletcher, “Against Universal Jurisdiction”, (2003) 1 J Int'l Crim Justice 580.

${ }^{203}$ Pierre Legrand, "The Impossibility of 'Legal Transplants"”, (1997) 4 Maastricht J Eur \& Comp L 111.

${ }^{204}$ See Charles Taylor, "The Politics of Recognition” in Amy Gutman (ed), Multiculturalism: Examining the Politics of Recognition (Princeton, NJ: Princeton University Press, 1994) 25.

${ }^{205}$ See James Tully, Strange Multiplicity: Constitutionalism in an Age of Diversity (Cambridge; New York: Cambridge University Press, 1995).

${ }^{206}$ For a critique of the deployment of the "politics of recognition" by "legal pluralist" theories, see St-Hilaire, Lutte, supra note 13.

${ }^{207}$ See S Harding, “Comparative Reasoning and Judicial Review”, (2003) 28 Yale J Int'1 L 409.

208 See Choudhry, supra note 9.

${ }^{209}$ See note 31, above, and accompanying text.

${ }^{210}$ See Choudhry, supra note 9, at 888, 890.

${ }^{211}$ See ibid, at 892.
} 
and a fortiori of its unification. Any nation is governed by laws common to mankind only in part, as Gaius already said. ${ }^{212}$ In 1896, Esmein took note of the fact that the respective constitutional laws of the "West's free nations" presented not only "family resemblances," but also ineradicable "individual traits." ${ }^{213}$ In 1976, without ever denying the ineradicability of a large sphere of cultural difference, Donald Kommers argued that "the study of comparative constitutional law can be a search for principles of justice and political obligation that transcend the culture bound opinions and conventions of a particular political community." ${ }^{214}$ At present, universalism becomes, for example, "ordered pluralism" in the work of Mireille Delmas-Marty, who asserts that, between the monist unification and the radical relativist pluralism, it is enough, for the "systematization" of a comparative law by means of a search for "harmonization" or the "settlement" of legal systems, that "the norms be close enough to the reference principle in order to be regarded as compatible." ${ }^{215}$ Even when this reference principle is, in fact, a standard, it still normally allows for a variety of ways to conform to it. The universalism on which the standardizing methodology is based makes it possible to avoid the Scylla of "excessive rationalization" and the Charybdis of the "radical cultural relativism." ${ }^{216}$ Indeed, the living experience of the modern Rule of Law is largely a pluralist one. ${ }^{217}$

It has been well said that "one should avoid de mystification of contexts." ${ }^{\text {"218 }}$ Indeed, in their impressive empirical study, Law et Versteeg have concluded that the claim "that formal constitutions serve an expressive function as statements of national identity" was seriously undermined by the fact "that constitutions tend to contain relatively standardized packages of rights. ${ }^{.219}$ Other research, including that of Kai Möller, corroborates this finding. ${ }^{220}$ Yet even in its dialogical version, culturalist contextualism is worried by the internationalization of particular national constitutional cultures authorized by a universalist comparativism. ${ }^{221}$ As Waldron observes, "[n]o doubt there is a lot that is ethnocentric" in the work of scholars who, as for instance Vitoria, have projected, as best they could, on the indigenous societies of the Americas the legal categories and principles derived from the European context with which they were familiar. Yet, as Waldron suggests, we can value such scholarship - not indeed in order "to congratulate our civilisation on its tolerance and humanity but to note that a self-referential starting point does not preclude the possibility of projection into an unfamiliar environment and

\footnotetext{
${ }^{212}$ See Waldron, Laws Common, supra note 10, at 5 (explaining that " $[t]$ he issue is not about global uniformity. The position propounded in that quotation from the Institutes is that although countries are governed partly by laws they share with the rest of humankind, they are still also partly governed by laws that are strictly their own").

${ }^{213}$ Esmein, supra note 92, at 22.

${ }^{214}$ Kommers, supra note 3, at 692.

${ }^{215}$ Delmas-Marty, supra note 6, at 70 .

${ }^{216}$ Ponthoreau, supra note 167 , at 30-32.

${ }^{217}$ See St-Hilaire, Lutte, supra note 13, at 420.

${ }^{218}$ Mahlmann, supra note 26, at 374.

${ }^{219}$ See Law and Versteeg, supra note 152, at 854.

${ }^{220}$ See especially Kai Moller, The Global Model of Constitutional Rights (Oxford, New York: Oxford University Press, 2012).

${ }^{221}$ See Choudhry, supra note 9, at 888 (arguing that "universalist interpretation, in general, will internationalize a nation's constitutional culture").
} 
further learning and development." ${ }^{222}$ In other words, the internationalizing projection of particular legal culture can sometimes be a stage in the ascertainment of areas of overlap between quite different legal cultures. Better yet, we might say that, in law as elsewhere, a (variable) measure of initial culture-centrism is the price of entry into any intercultural dialogue. Besides, pace some philosophers, jurists, and politicians, cultural spaces are neither monolithic nor static. ${ }^{223}$ Complex processes, not necessarily of deculturation, but of acculturation involve not only the legal cultures of nations or communities, but also a global culture of human rights. ${ }^{224}$ And to any objectifying attempt at freezing a legal culture the better to protect it, one must object that law is also the subject of dispute, which can modify it, whether to bring it closer to or to move it further away from a better implementation of equality, the most basic of legal principles. ${ }^{225}$ In the United States, for instance, the doctrinal and scholarly understanding of the principle of the $14^{\text {th }}$ Amendment has evolved considerably, and with it the American constitutional and legal "culture."

To an approach that sees context as insuperable, we should prefer that, theorized notably by Ernst Rabel, ${ }^{226}$ Max Rheinstein, ${ }^{227}$ Otto Kahn-Freund, ${ }^{228}$ Konrad Zweigert, and Hein Kötz, ${ }^{229}$ which directs most brilliant contributions to comparative law - functionalism, including in the realm of constitutional law. ${ }^{230}$ As the works of, in particular, Norman Dorsen, Michel Rosenfeld, András Sajo and Susanne Baer ${ }^{231}$ show, once it has been, of course, situated in its context, the functional equivalent has a role to play in the comparison of constitutional and public laws. ${ }^{232}$ By creating types, the functional method of looking for equivalents makes the mass of national, regional, and international laws intelligible. As Guillaume Tusseau's study of constitutional justice brilliantly demonstrates, typologization must, insofar as possible, operate a posteriori, after a real study of positive law, rather than a priori, taking the shape of what Tusseau calls great scholarly

\footnotetext{
${ }^{222}$ Waldron, Laws Common, supra note 10, at 202.

${ }^{223}$ See Denys Cuche, La notion de culture dans les sciences sociales, (La Découverte, 2001).

${ }^{224}$ See Lawrence M Friedman, The Human Rights Culture: A Study in History and Context (New Orleans, LA: Quid Pro Books, 2011).

${ }^{225}$ See St-Hilaire, Lutte, supra note 13.

${ }^{226}$ Voir Ernst Rabel, The Conflict of Laws: A Comparative Study, 4 vol, (Ann Arbor, MI: University of Michigan Press, 1945-1958; electronic ed, West, 2008).

${ }^{227}$ See Max Rheinstein, Gesammelte Schriften / Collected Works, Hans Georg Leser (ed), (Tübingen: Mohr, 1979).

${ }^{228}$ Otto Kahn-Freund, "On Uses and Misuses of Comparative Law”, (1974) 37 Modern L Rev 1. See also Otto KahnFreund, Comparative Law as an Academic Subject, (Oxford: Clarendon Press, 1965).

${ }^{229}$ See Konrad Zweigert and Hein Kötz, Einführung in die Rechtsvergleichung auf dem Gebiete des Privatrechts, 2 vol, (Tübingen: Mohr, 1969-1971) (An Introduction to Comparative Law, Tony Weir, transl, 2 vol, $3^{\text {rd }}$ rev ed (Oxford: Clarendon Press, 1998).

${ }^{230}$ See Vicky Jackson, "Comparative Constitutional Law: Methodologies", in Rosenfeld and Sajó (eds), supra note 26,54 at 62 .

${ }^{231}$ Norman Dorsen, Michel Rosenfeld, András Sajó and Susanne Baer, Comparative Constitutionalism. Cases and Materials, (St Paul, MN: West, 2003).

${ }^{232}$ See Ponthoreau, supra note 167, at 47.
} 
"models." The danger of the latter approach is to fall prey to the "legalist illusion" which, moreover, can mask a programme that is more political than legal. ${ }^{233}$

Yet while Zweigert is right that the functional methodology of comparative law must be immediately followed by a "critical appreciation," 234 in reality, functionalist comparativism does not by itself provide the operating method of valuing certain types above others. At present, functionalist and universalist approaches tend to be opposed to each other as, respectively, descriptive and normative, even though, in order to complement each other, they ought to be interconnected. As Vicky Jackson points out, this opposition is given substantive explanations. The comparative constitutional law relative to government structure is said only to be amenable to descriptive study, while that relative to fundamental rights is supposed to lend itself more easily to normative inquiry. ${ }^{235}$ And "[y] et the search for 'just principles' of human rights law may be no more theoretical or universalist than the search for 'good' principles of government design. ${ }^{, 236}$ Kommers, for instance, has long been demonstrating that a universalist approach to comparative constitutional law is also possible in the realm of federalism. ${ }^{237}$ Besides, the ius gentium relative to fundamental rights has already been having an effect on its structural counterpart - witness the manner in which the principle of proportionality has been radiating on the global federative heritage relative to the settlement of division of powers disputes. ${ }^{238}$ According to Jackson, the comparison of structural legal constitutions sometimes hides a normative inquiry behind what the use of functionalist "methods" or "techniques" would suggest. ${ }^{239}$ This is no doubt suggestive, but does not answer the question of how the functional method can be deployed by the universalist approach to the comparative law of fundamental constitutional rights. Nor does it exactly answer the question of how, that is to say by which specific "technique," the functional method can serve a universalist approach of constitutional law, that of fundamental rights as well as of structure. The only indication that Jackson gives in this respect is that this technique differs from merely resorting to international law. My own answer is that this technique is precisely that of global standards.

\footnotetext{
${ }^{233}$ Guillaume Tusseau, Contre les « modèles » de justice constitutionnelle. Essai de critique méthodologique, French and Italian bilingual ed, (Bologna: Bononia University Press, 2009).

${ }^{234}$ Konrad Zweiger, "Méthodologie du droit comparé", in Mélanges offerts à Jacques Maury, vol I, (Paris: DallozSirey, 1960) 579 at 596.

235 Jackson, supra note 230, at 62 (arguing that "universalist justice-seeking approaches to comparative constitutional law most typically, though not inevitably, entail comparative work on rights, often linked with literature on human rights. By contrast, functionalist approaches ... are often deployed in analyzing structural issues, for instance different forms of federalism, or presidentialism, or voting structures. For this reason, universalist scholarship about rights has tended to bring together work on comparative constitutional law with work on international law and especially international human rights and humanitarian law")

236 Ibid

${ }^{237}$ See Kommers, supra note 3, at 690-691.

${ }^{238}$ See Mariel Gonzàlez Pascual, "Methods of Interpreting Competence Norms: Judicial Allocation of Powers in a Comparative Perspective", (2013) 14:8 German LJ 1501 at 1515, 1517 and 1519.

${ }^{239}$ Jackson, supra note 230, at 62-63 (claiming that "[ $\left.\mathrm{t}\right]$ he goals of functional comparison may be as normative and universalistically theory-seeking as others ... but the techniques used focus more on specific functional comparisons and questions of causation, rather than on the moral, principled appeal of comparative approaches").
} 


\subsection{From Typology to Valuing, and from Standards (back) to Principles}

Obviously, the issue of valuing one type of practices rather than another can only arise in the presence of a plurality of types. Hence it is possible to speak of the "Generic Bill of Rights," modeled by Law and Versteeg on the basis of a "rights index" which they themselves developed from a database of 729 constitutions enacted and ratified by 188 states between 1946 à $2006,{ }^{240}$ as a standard. Most of the time, however, a comparative constitutionalist will be faced with a plurality of types, so that valuing one or some of them rather than the others will require a criterion, a benchmark. It will then be possible to refer to the general principles of the modern Rule of Law, and the indicators derived from them. However, before doing so, it will be necessary - following an epistemology which, as we can easily see, favours the more positive sources and allows resorting to the less positive ones only so far as necessary - to consult supranational, regional, or international law, and in particular that relative to human rights. As we have seen, by being made fundamental, human rights are at the heart of the modern Rule of Law state. It is indeed an integral part of the Venice Commission's method, not systematically to follow, but to maintain a dialogue with the European Court of Human Rights. Its 2012 opinion on the Hungarian judicial system is illustrative, as it refers, in the matter of the distribution of cases among judges, to the case law relative to article 6 of the ECHR, which protects the right to a fair trial. $^{241}$

The combination of comparative constitutional law and the taking into account of international human rights law regularly contributes to valuing certain types rather than others, and thus to the ascertainment of standards. But these, in return, tend to enrich the interpretation of principles. The road which the science of constitutional law travels from principles to standards is a two-way one, so that moving from standards to principles is equally possible. A sort of reflective equilibrium, its interpretive equilibrium can only be maintained by means of incessant back-andforth movement. This is how we should understand Waldron's claim that "[t]hough it is important to distinguish ius gentium ... from international law properly so-called, ... one of its most important manifestations is in international human rights law, particularly associated with a sort of overlap between the fundamental rights provisions of national constitutions and bills and charters or rights." ${ }^{242}$ Similarly, Kai Möller concludes that the "moral structure" of the fundamental rights guaranteed by national systems of constitutional law is identical to that of the human rights guaranteed by international law. ${ }^{243}$

\footnotetext{
${ }^{240}$ Law and Versteeg, supra note 152 , at 770-79.

${ }^{241}$ European Commission for democracy through law (Venice Commission), Opinion on Act CLXII of 2011 on the Legal Status and Remuneration of Judges and Act CLXI of 2011 on the Organisation and Administration of Courts of Hungary, CDL-AD(2012)001 at paras 86-94, online: <http://www.venice.coe.int/webforms/documents/CDL$\mathrm{AD}(2012) 001 . \operatorname{aspx}>$.

${ }^{242}$ Waldron, Laws Common, supra note 10, at 32.

${ }^{243}$ See Kai Moller, "From constitutional to human rights: On the moral structure of international human rights", (2014) 3:3 Global Constitutionalism, 373.
} 
Lastly, besides supranational law, the linkage between a functional spectrum of typical practices and the principles and indicators of the modern Rule of Law must always take into account what I would call the general facts established, if only provisionally, by the humanities and the social sciences. Among these facts are those which relate to the true role played by political parties within the processes of contemporary processes of representative democracy; those that have to do with the situation of vulnerable persons who are or have been imprisoned, migrants, stateless individuals, or members of national minorities or an indigenous people, to give but a few examples. So much for the "how." There remains the "who" - the question of whose role it is to ascertain the global standards of constitutional law.

\subsection{Actors}

Together with ius gentium, of which they ought to be regarded as a component, the global standards of constitutional law constitute a substantive source of law that is only an indirect product of the formal sources of positive law. More precisely, it is a metasource, that is to say a source that can encompass others, among which one might expect to find legal scholarship. To be sure, the scholars, who are largely responsible for the principled reconstruction of the modern Rule of Law, do contribute to it. For now, however, it is not they, but international or national state organs that employ the standardizing method. The work of the Select Committee on the Constitution of the United Kingdom's House of Lords is certainly an interesting case. The standards which can be derived from its opinions have recently been codified by the members of the Constitution Unit of the Univerity College London. ${ }^{244}$ But foremost among the standards researchers are a broad advisory organ of the Council of Europe, the European Commission for Democracy through Law (the Venice Commission); a mixed organ of the Venice Commission, the Counsil for Democratic Elections; and the OSCE's Office for Democratic Institutions and Human Rights.

When it was created in 1990, the Venice Commission was tasked with offering constitutional assistance to Central European nations, a mission expanded to the new republics of Eastern Europe the following year, with the fall of the USSR. While that mission remains crucial, the Commission's work has expanded into new areas substantively as well geographically. The Venice Commission now advises not only on constitutional matters in the strict sense of the word, but also on subjects having to do with the judiciary, elections, referenda, and political parties. Among its members, an increasing number of Western and Northern Europe have resorted to its services. Orginally set up by a partial agreement among 18 member states of the Council of Europe, it is, since 2002, when all of the member states joined it, governed by a broadened agreement which allows non-European states to become full members, so that its work

\footnotetext{
${ }^{244}$ See Jack Simson Caird, Robert Hazell and Dawn Oliver, The Constitutional Standards of the House of Lords Select Committee on the Constitution, The Constitution Unit, School of Public Policy, University College London, 2014, online: $<$ https://www.ucl.ac.uk/constitution-unit/publications/tabs/reports/edit/unit-publications/159>.
} 
increasingly tends to reflect a global, rather a merely European, constitutional heritage. In addition to the 47 member states of the Council of Europe, the Commission has 12 additional members (for a total of 59): Marocco, Algeria, Tunisia, Israel, Kirghizistan, Kazakhstan, South Korea, Mexico, Brazil, Chili, Peru, and the United States. ${ }^{245}$ Belarus has the status of an associate member; Argentina, Canada, Uruguay, Japan, and the Vatican that of observers. South Africa, the Palestinian Authority, and the European Commission have a special status. Most often after considering, patiently and prudently, multiple ad hoc opinions, the Commission has produced a number of reference documents on general subjects such as: constitutional amendment ${ }^{246}$; secession $^{247}$; federated entities and international treaties ${ }^{248}$; the role of parliamentary opposition $^{249}$; the imperative mandate ${ }^{250}$; legislative second chambers ${ }^{251}$; parliamentary immunities $^{252}$; the choice of election dates ${ }^{253}$; legislative initiative ${ }^{254}$; election law ${ }^{255}$; referendum

${ }^{245}$ However, article 2.5 of the Commission's Revised Statute decrees that "[m]embers appointed by non-member states of the Council of Europe shall not be entitled to vote on questions raised by the statutory bodies of the Council of Europe."

${ }^{246}$ European Commission for democracy through law (Venice Commission), Report on Constitutional Amendment, CDL-AD(2010)001, online : <http://www.venice.coe.int/webforms/documents/?pdf=CDL-AD(2010)001-e>.

${ }^{247}$ European Commission for democracy through law (Venice Commission), Self-Determination and Secession in Constitutional Law, CDL-INF(2000)002, online: $<$ http://www.venice.coe.int/webforms/documents/?pdf=CDL$\operatorname{INF}(2000) 002-\mathrm{e}>$.

${ }^{248}$ European Commission for democracy through law (Venice Commission), Federated and Regional $s$ Entities and International Treaties, CDL-INF(2000)003, online : $<$ http://www.venice.coe.int/webforms/documents/?pdf=CDL$\operatorname{INF}(2000) 003-\mathrm{e}>$.

${ }^{249}$ European Commission for democracy through law (Venice Commission), Report on the role of the opposition in a democratic Parliament, CDL-AD(2010)025, online : < http://www.venice.coe.int/webforms/documents/CDL$\mathrm{AD}(2010) 025 . \operatorname{aspx}>$.

${ }^{250}$ European Commission for democracy through law (Venice Commission), Report on the Imperative Mandate and Similar Practices, CDL-AD(2009)027, online : <http://www.venice.coe.int/webforms/documents/CDL$\mathrm{AD}(2009) 027 . \operatorname{aspx}>$.

${ }^{251}$ Venice Commission, "Second Chambers", supra note 192.

${ }^{252}$ European Commission for democracy through law (Venice Commission), Report on the scope and lifting of parliamentary immunities, CDL-AD(2014)011, online : $<\mathrm{http} / / \mathrm{www} . v e n i c e . c o e . i n t / w e b f o r m s / d o c u m e n t s / C D L-$ $\mathrm{AD}(2014) 011$. aspx >; Comparative Table on the lifting of parliamentary immunity, CDL(2013)043, online : $<$ http://www.venice.coe.int/webforms/documents/CDL(2013)043.aspx >; Report on the regime of parliamentary immunity, CDL-INF(1996)007, online : <http://www.venice.coe.int/webforms/documents/CDL-INF(1996)007.aspx $>$.

${ }^{253}$ European Commission for democracy through law (Venice Commission), Report on choosing the date of an election, CDL-AD(2007)037, online : <http://www.venice.coe.int/webforms/documents/CDL-AD(2007)037.aspx>. ${ }^{254}$ European Commission for democracy through law (Venice Commission), Report on Legislative Initiative, CDL$\mathrm{AD}(2008) 035$, online : <http://www.venice.coe.int/webforms/documents/CDL-AD(2008)035.aspx>.

${ }^{255}$ Venice Commission, Electoral Matters, supra note 193; European Commission for democracy through law (Venice Commission), Report on Electoral Systems - Overview of available solutions and selection criteria, CDL$\mathrm{AD}(2004) 003$, online : <http://www.venice.coe.int/webforms/documents/CDL-AD(2004)003.aspx>; European Commission for democracy through law (Venice Commission), Report on the compatibility of remote voting and electronic voting with the standards of the Council of Europe, CDL-AD(2004)012, online: $<\mathrm{http} / /$ www.venice.coe.int/webforms/documents/CDL-AD(2004)012.aspx>; European Commission for democracy through law (Venice Commission) Report on the abolition of restrictions on the right to vote in general elections, CDL-AD(2005)011, online : <http://www.venice.coe.int/webforms/documents/CDL-AD(2005)011.aspx>; European Commission for democracy through law (Venice Commission) Report on the abolition of restrictions on the right to vote in general elections, CDL-AD(2005)012, online : <http://www.venice.coe.int/webforms/documents/CDL$\mathrm{AD}(2005) 012$.asp $\mathrm{x}>$; European Commission for democracy through law (Venice Commission), Interpretative Declaration on the Stability of the Electoral Law, CDL-AD(2005)043, online : 
law $^{256}$; law relative to political parties ${ }^{257}$; judicial appointments ${ }^{258}$ and the composition of constitutional courts $^{259}$; judicial indepedence ${ }^{260}$; individual access to constitutional justice ${ }^{261}$; the

$<$ http://www.venice.coe.int/webforms/documents/CDL-AD(2005)043.aspx >; European Commission for democracy through law (Venice Commission), Report on Electoral Law and Electoral Administration in Europe -Synthesis study on recurrent challenges and problematic issues, CDL-AD(2006)018, online : <

http://www.venice.coe.int/webforms/documents/CDL-AD(2006)018.aspx>; European Commission for democracy through law (Venice Commission), Election Evaluation Guide, CDL-AD(2006)021, online : <

http://www.venice.coe.int/webforms/documents/CDL-AD(2006)021.aspx>; European Commission for democracy through law (Venice Commission), Comparative Report on thresholds and other features of electoral systems which bar parties from access to Parliament, CDL-AD(2008)037, online :

$<$ http://www.venice.coe.int/webforms/documents/CDL-AD(2008)037.aspx>; European Commission for democracy through law (Venice Commission), Guidelines on Media Analysis during Election Observation Missions), CDL$\mathrm{AD}(2009) 031$, online : < http://www.venice.coe.int/webforms/documents/CDL-AD(2009)031.aspx>; European Commission for democracy through law (Venice Commission), Report on the cancellation of election result, CDL$\mathrm{AD}(2009) 054$, online : < http://www.venice.coe.int/webforms/documents/CDL-AD(2009)054.aspx>; European Commission for democracy through law (Venice Commission), Guidelines on an internationally recognised status of election observers, CDL-AD(2009)059, online : <http://www.venice.coe.int/webforms/documents/CDL$\mathrm{AD}(2009) 059$. asp $>$; European Commission for democracy through law (Venice Commission), Report on Thresholds and other features of electoral systems which bar parties from access to Parliament (II), CDL$\mathrm{AD}(2010) 007$, online : <http://www.venice.coe.int/webforms/documents/CDL-AD(2010)007.aspx>; European Commission for democracy through law (Venice Commission), Report on the timeline and inventory of political criteria for assessing an election, CDL-AD(2010)037, online :

$<\mathrm{http}$ ://www.venice.coe.int/webforms/documents/CDL-AD(2010)037.aspx>; European Commission for democracy through law (Venice Commission), Report on figure based management of possible election fraud, CDL$\mathrm{AD}(2010) 043$, online : <http://www.venice.coe.int/webforms/documents/CDL-AD(2010)043.aspx>; European Commission for democracy through law (Venice Commission), Report on out-of-country voting, CDL-AD(2011)022 online: <http://www.venice.coe.int/webforms/documents/CDL-AD(2011)022.aspx>; European Commission for democracy through law (Venice Commission), Declaration of Global Principles for non-partisan election observation and monitoring by citizen organizations and Code of Conduct for non-partisan citizen election observers and monitors - Commemorated 3 April 2012 at the United Nations, New York - Initiated by the Global Network of Domestic Election Monitors (GNDEM), CDL-AD(2012)018, online :

$<\mathrm{http} / / / \mathrm{www} . v e n i c e . c o e . i n t /$ webforms/documents/CDL-AD(2012)018.aspx>.

${ }^{256}$ European Commission for democracy through law (Venice Commission), Code of good practice on Referendums, CDL-AD(2007)008rev, online : <http://www.venice.coe.int/webforms/documents/CDL-AD(2007)008rev.aspx>.

${ }^{257}$ European Commission for democracy through law (Venice Commission), Guidelines on political party regulation, CDL-AD(2010)024, online : <http://www.venice.coe.int/webforms/documents/CDL-

AD(2010)024.aspx>; Venice Commission, Political Parties, supra note 194; Report on the Participation of Political Parties in Elections, CDL-AD(2006)025, online : <http://www.venice.coe.int/webforms/documents/CDL$\mathrm{AD}(2006) 025 . a s p \mathrm{x}>$; European Commission for democracy through law (Venice Commission), Opinion on the Prohibition of Financial Contributions to Political Parties from Foreign Sources, CDL-AD(2006)014, online : $<$ http://www.venice.coe.int/webforms/documents/CDL-AD(2006)014.aspx>; European Commission for democracy through law (Venice Commission), Guidelines and Report on the Financing of Political Parties, CDLINF(2001)008, online : <http://www.venice.coe.int/webforms/documents/CDL-INF(2001)008.aspx>; European Commission for democracy through law (Venice Commission), Guidelines on prohibition and dissolution of political parties and analogous measures, CDL-INF(2000)001, online : $<$ http://www.venice.coe.int/webforms/documents/CDL-INF(2000)001.aspx>.

${ }^{258}$ Venice Commission, Judicial Appointments, supra note 195.

${ }^{259}$ European Commission for democracy through law (Venice Commission), The composition of constitutional courts, CDL-STD(1997)020, online : <http://www.venice.coe.int/webforms/documents/CDL-STD(1997)020.aspx>. ${ }^{260}$ European Commission for democracy through law (Venice Commission), Report on the Independence of the Judicial System Part I: The Independence of Judges, CDL-AD(2010)004, online :

$<$ http://www.venice.coe.int/webforms/documents/CDL-AD(2010)004.aspx>; European Commission for democracy through law (Venice Commission), Report on European Standards as regards the Independence of the Judicial 
execution of the decisions of constitutional courts ${ }^{262}$; human rights in emergency situations ${ }^{263}$; counter-terrorism $^{264}$; the freedom of peaceful assembly ${ }^{265}$; the freedoms of expression and religion ${ }^{266}$; the representation and political participation of women $^{267}$; the political participation of people with disabilities ${ }^{268}$; national minorities members' rights ${ }^{269}$; democratic control over armed forces and security services ${ }^{270}$; video-surveillance ${ }^{271}$; and private military and security

System: Part II - the Prosecution Service, CDL-AD(2010)040, online :

$<\mathrm{http} / / / \mathrm{www} . v e n i c e . c o e$. int/webforms/documents/CDL-AD(2010)040.aspx>.

${ }^{261}$ European Commission for democracy through law (Venice Commission), Study on individual access to constitutional justice, CDL-AD(2010)039rev, online : <http://www.venice.coe.int/webforms/documents/CDL$\operatorname{AD}(2010) 039$ rev.aspx>.

${ }^{262}$ European Commission for democracy through law (Venice Commission), Decisions of constitutional courts and equivalent bodies and their execution, CDL-INF(2001)009, online :

$<$ http://www.venice.coe.int/webforms/documents/CDL-INF(2001)009.aspx>.

${ }^{263}$ European Commission for democracy through law (Venice Commission), Opinion on the Protection of Human

Rights in Emergency Situations, CDL-AD(2006)015, online :

$<$ http://www.venice.coe.int/webforms/documents/CDL-AD(2006)015.aspx>.

${ }^{264}$ European Commission for democracy through law (Venice Commission), Report on Counter-terrorism Measures and Human Rights, CDL-AD(2010)022, online : <http://www.venice.coe.int/webforms/documents/CDL$\mathrm{AD}(2010) 022 . \operatorname{aspx}>$.

${ }^{265}$ European Commission for democracy through law (Venice Commission), OSCE/ODIHR - Venice Commission Guidelines on Freedom of Peaceful Assembly $\left(2^{\text {nd }}\right.$ ed), CDL-AD(2010)020, online :

$<$ http://www.venice.coe.int/webforms/documents/CDL-AD(2010)020.aspx>.

${ }^{266}$ European Commission for democracy through law (Venice Commission), Report on the relationship between Freedom of Expression and Freedom of Religion: the issue of regulation and prosecution of Blasphemy, Religious Insult and Incitement to Religious Hatred, CDL-AD(2008)026, online :

$<\mathrm{http} / / / \mathrm{www} . v e n i c e . c o e . i n t /$ webforms/documents/CDL-AD(2008)026.aspx>.

${ }^{267}$ European Commission for democracy through law (Venice Commission), Report on the Impact of Electoral Systems on Women's Representation in Politics, CDL-AD(2009)029, online : < http://www.venice.coe.int/webforms/documents/CDL-AD(2009)029.aspx $>$; Declaration on Women's Participation in Elections, CDL-AD(2006)020, online : <http://www.venice.coe.int/webforms/documents/CDL$\mathrm{AD}(2006) 020 . \operatorname{aspx}>$.

${ }^{268}$ European Commission for democracy through law (Venice Commission), Revised interpretative declaration to the code of good practice in electoral matters on the participation of people with disabilities in elections, CDL$\mathrm{AD}(2011) 045$, online : <http://www.venice.coe.int/webforms/documents/CDL-AD(2011)045.aspx>.

${ }^{269}$ Venice Commission, "Dual Voting", supra note 191; European Commission for democracy through law (Venice Commission), Report on Electoral Rules and Affirmative Action for National Minorities' Participation in DecisionMaking Process in European Countries, CDL-AD(2005)009, online:

$<$ http://www.venice.coe.int/webforms/documents/CDL-AD(2005)009.aspx>; European Commission for democracy through law (Venice Commission), Report on the Preferential Treatment of National Minorities by Their Kin-State, CDL-INF(2001)019, online: <http://www.venice.coe.int/webforms/documents/?pdf=CDL-INF(2001)019-e >.

${ }^{270}$ European Commission for democracy through law (Venice Commission), Report on the Democratic Control of the Armed Forces, CDL-AD(2008)004, online : <http://www.venice.coe.int/webforms/documents/CDL$\mathrm{AD}(2008) 004$.aspx>; European Commission for democracy through law (Venice Commission), Report on the Democratic oversight of the Security Services, CDL-AD(2007)016, online :

$<$ http://www.venice.coe.int/webforms/documents/CDL-AD(2007)016.aspx>.

${ }^{271}$ European Commission for democracy through law (Venice Commission), Opinion on Video Surveillance in Public Places by Public Authorities and the Protection of Human Rights, CDL-AD(2007)014, online : < http://www.venice.coe.int/webforms/documents/CDL-AD(2007)014.aspx>. 
firms. ${ }^{272}$ So much for the participants in the direct production of the global standards of constitutional law.

Let us now consider the participants in their indirect production, that is to say the formal sources of law - legislation and case law. It is constitutional legislation and case law that we focus on here. The more the output of the world's constitution-makers and constitutional courts substantially converges, more precisely, the more it converges in the direction of a greater conformity to international law, as well as system of principles of the modern Rule of Law, the easier the scientific work of ascertainment of global standards of constitutional law becomes.

Jackson observes that, "[a]lthough scholarly work in recent years has begun to focus more attention on legislators both as constitution-makers and as constitutional interpreters, empirical work has not kept pace with theoretical developments." 273 Among the rare examples of empirical research on the activity of the world's constitution-makers, Law and Versteeg's study deserves to be highlighted, although it is important to keep in mind that it largely focused on the entrenchment of rights, and only incidentally considered structural provisions. Law and Versteeg came to the following general conclusions. First, the influence of the Constitution of the United States on the world's constitution-makers is in decline, notably since the 1990s, although it could have been expected that it would continue to serve as a model at that point, as numerous nations of Central and Eastern Europe gave themselves new constitutions, while others, in Africa and Asia, undertook revisions to theirs. ${ }^{274}$ Second, while the Canadian Charter of Rights and Freedoms, contained in Part I of the Canadian Constitution Act, 1982, is more in step with the prevailing global constitutional standards, it is at best a culturally hegemonic model, appealing to common law countries, rather than a globally hegemonic model similar to what the American Constitution once was. ${ }^{275}$ Third, with the possible exception of the Universal Declaration of Human Rights, no international or regional instrument seems to play this role of hegemonic model (at the regional or global scale). Fourth, this general polycentrism of the influence exercised by national constitutions and international and regional instruments on constitutionmakers suggests that the global standards of constitutional law relative to fundamental rights

\footnotetext{
${ }^{272}$ European Commission for democracy through law (Venice Commission), Report on Private Military and Security Firms and Erosion of the State Monopoly on the use of force, CDL-AD(2009)038, online :

$<$ http://www.venice.coe.int/webforms/documents/CDL-AD(2009)038.aspx>.

${ }^{273}$ Jackson, supra note 230, at 69.

${ }^{274}$ Law and Versteeg, supra note 152, at 781-82.

${ }^{275} \mathrm{Ibid}$, at 810-11 (observing that "[t]he Canadian Constitution has often been described as more consistent with, and more influential upon, prevailing global standards and practices than the U.S. Constitution. The Canadian Charter of Rights and Freedoms, which was adopted in conjunction with the patriation of the Canadian Constitution in 1982, has been described as the leading influence upon the drafting of the South African Bill of Rights, the Israeli Basic Laws, the New Zealand Bill of Rights, and the Hong Kong Bill of Rights, amongst others. ... The data suggest that the Canadian model enjoys greater popularity than the American model but, at the same time, possesses only limited appeal beyond a particular subset of countries. Initial analysis of the data reveals that the Canadian Constitution, unlike the U.S. Constitution, is increasingly in sync with global constitutionalism") and 820-21 (asserting that "the most plausible inference to draw from our empirical findings is that Canada is, at least to some degree, a constitutional trendsetter among common law countries").
} 
follow a principled evolutionary logic, a dynamic, a groundswell, which increasingly tends to favour civil and political rights, at the expense of economic, social, and cultural rights. ${ }^{276} \mathrm{Fifth}$, the evolutionary dimension of the global standards of constitutional law thus revealed, it becomes easy to see why the old and rigid (and hence only rarely modified) ${ }^{277}$ Constitution of the United States is losing its influence. ${ }^{278}$ While it is true that, the more the output of the world's constitution-makers substantively converges in the direction of a greater conformity to the principled system of the modern Rule of Law, the easier the scientific work of ascertaining global standards of constitutonal law becomes, it remains the case that, the closer a given constitution is to these standards, the more likely it is to be influential abroad, not only with constitution-makers but also with judges.

Some constitutional or supreme courts, or indeed individual judges, contribute more than others to the convergence, the "cross-pollination" 279 of the world's constitutional jurisprudences towards a better implementation of the modern Rule of Law. Paragraph 39(1)(c) of the South African Constitution, for example, expressly provides that any "court, tribunal or forum" competent to apply the Bill of Rights "may consider foreign law." Such an express authorization undoubtedly represents the most obvious and best-known case of the fertilization of one jurisprudence by others, but it is far from being the only one. ${ }^{280}$ On the one hand, taking foreign law into account as a substantive source of law is a common judicial practice, which developed without any express authorization. For example, the Judicial Committee of the Privy Council largely resorted

\footnotetext{
${ }^{276} \mathrm{Ibid}$, at 837 (asserting that "[a]s an empirical matter, ... very little is known about the impact of international human rights instruments on constitution writing at the national level"), 838 (arguing that "[ $t]$ he fact that the average constitution resembles the hybrid UDHR more closely than either the ICCPR or ICESCR reflects the tendency of constitutions to contain a combination of both first- and second- generation rights. Over time, the ICCPR has been catching up in popularity to the UDHR, which suggests a growing constitutional tilt in favor of the kinds of negative civil and political rights found in the ICCPR. By contrast, the historically low levels of constitutonal similarity to the ICESCR imply that it has been rare for constitutions to focus upon socioeconomic rights to the exclusion of civil and political rights"), 846 (arguing that "[ $t$ ]he most plausible interpretation of this sequence of events is that regional human rights instruments do not actually generate global consensus as to what rights demand formal constitutional entrenchment, but instead express and perhaps reinforce trends that have already begun to emerge. Yet even the relatively modest claim that regional human rights instruments express or reinforce emerging global trends does not always hold true"), 849 (asserting that "[a]s in the case of the international human rights instruments, our analysis offers little support for the claim that any of the four regional human rights instruments has changed the way in which constitutions are written, even within their respective regions. ... Most notably, the fact that a country falls within the region governed by a particular treaty does not mean that its constitution will resemble the treaty more closely"), 850 (stating that "[o]verall, our analysis uncovers no clear evidence that transnational human rights instruments are shaping global or even regional trends in constitution writings, much less that they have dispaced the U.S. Constitution as a source of inspiration for constitution makers").

${ }^{277}$ See John R. Vile, "Constitutional Revision in the United States of America", in Zenophon Contiades (ed), Engineering Constitutional Change: A Comparative Perspective on Europe, Canada, and the USA, (London: Routledge, 2013) 389.

${ }^{278}$ Law and Versteeg, supra note 152, at 855 (asserting that "[o]nce global constitutionalism is understood as the product of a polycentric evolutionary process, it is not difficult to see why the U.S. Constitution is playing an increasingly peripheral role in that process. No evolutionary process favors a species that is frozen in time. At least some of the responsibility for the declining global appeal of American constitutionalism lies not with the Supreme Court, or with a broader penchant for exceptionalism, but rather with the static character of the Constitution itself").

${ }^{279}$ See Anne-Marie Slaughter, “A Global Community of Courts”, (2003) 44:1 Harv Int'l LJ 191 at 194-204.

${ }^{280} \mathrm{See} i b i d$, at $828-29$.
} 
to it in the constitutional law of federalism. ${ }^{281}$ On the other hand, judges do not always cite or reference the foreign sources from which they borrow, whether they are specifically authorized to do so or not, their "prudential silence" thus starting a "silent dialogue.,"282

In collaboration with the Venice Commission's Joint Council on Constitutional Justice, this cross-pollination of constitutional jurisprudences is promoted and supported by initiatives such as the World Conference on Constitutional Justice, as well as associations of constitutional judges such as that of francophone constitutional courts, the Association des cours constitutionnelles ayant en partage l'usage du français (ACCPUF). Indeed, the ACCPUF is a manifestation of a broader phenomenon of the emergence or, by now, even of the consolidation of what Anne-Marie Slaughter has aptly called a global community of courts. ${ }^{283}$ This phenomenon is not so much institutional as cultural or, more accurately, an element of the judges' professional consciousness. ${ }^{284}$ But even if it is true that it contributes to the (re)generation of a "global legal system," 285 we would do well to understand it, with Waldron's help, as ius gentium of secondorder positivity.

In 1989, on the occasion of the $40^{\text {th }}$ anniversary of the German Grundgesetz, the Chief Justice of the Supreme Court of the United States, William Rehnquist, said:

For nearly a century and a half, courts in the United States exercising the power of judicial review had no precedents to look to save their own, because our courts alone exercised this sort of authority. When many new constitutional courts were created after the Second World War, these courts naturally looked to decisions of the Supreme Court of the United States ... But now that constitutional law is solidly grounded in so many countries, it is time that the United States courts begin looking to the decisions of other constitutional courts to aid in their own deliberative process. The United States courts, and legal scholarship in our country generally, have been somewhat laggard in relying on comparative law and decisions of other countries. But I predict that with so many thriving constitutional courts in the world today... that approach will be changed in the near future. ${ }^{286}$

It is notorious that this prediction did not come true. ${ }^{287}$ Referring to foreign law in constitutional cases can even amount to something "dangerous," according to Justice Scalia, who took this position in a dissenting judgment which Chief Justice Rehnquist actually joined. ${ }^{288}$ The relatively

\footnotetext{
${ }^{281}$ See eg AG Australia v. Colonial Sugar Refining Company, [1914] AC 237.

${ }^{282}$ See Jackson, supra note 230, at 60.

${ }^{283}$ Slaughter, supra note 279.

${ }^{284}$ See ibid, at 192-93.

${ }^{285} \mathrm{Ibid}$, at 218 (asserting that "[ $\mathrm{t}$ ]his dialogue [between the adjudicative bodies of the world community], and the emergence of a community of courts, may be as close as it is possible to come to a formal global system"). See also Anne-Marie Slaughter, A New World Order, (Princeton, NJ: Princeton University Press, 2004) at 67.

${ }^{286}$ William Rehnquist, "Constitutional Courts-Comparative Remarks", in Paul Krichhof and Donald P Kommers (eds), Germany and its Basic Law: Past, Present and Future-A German-American Symposium, (Baden-Baden: Nomos, 1993) at 411-412.

${ }^{287}$ Michel Rosenfeld, “Le constitutionnalisme comparé en mouvement : d'une controverse américaine sur les références jurisprudentielles au droit étranger", in Pierre Legrand (ed), Comparer les droits, résolument, (Paris: Presses Universitaires de France, 2009) 561; Waldron, Laws Common, supra note 10, at 1-23.

${ }^{288}$ Lawrence v Texas, (2003) 539 US 558 at 598.
} 
closed character of the constitutional jurisprudence adds itself to the relative obsolescence of the Constitution as a cause of the decline of influence of the American constitutional law, which even tends to serve increasingly as an anti-model, a bank of dissuasive precedents. ${ }^{289}$

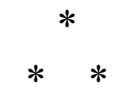

With the new science of constitutional law as ius gentium and comparative constitutional law, the method of global standards of constitutional law will meet various resisting forces. According to Waldron, what truly separates those who oppose the consideration of foreign law and those who promote it is not the gap between the parochialism of the former and the cosmopolitanism of the latter group, but rather that between law conceived as will and law conceived as reason. As reason ultimately remains faith, we can say, paradoxically, that the main force resisting the notion of global standards of constitutional law is the lack of faith... in legal reason. Indeed, Roberto Unger's quip is well-known: with the emergence of the Critical Legal Studies movement, the legal profession became "like a priesthood that had lost their faith and kept their jobs." 290 That movement's purported contribution was to have done away with the faith.

Yet as Tamanaha reminds us, "[t]he legal profession ... is located at the crux of the rule of law. ... [T] he rule of law could not conceivably function without this group committed to the values of legality." ${ }^{291}$ But how can the jurists express a professional commitment to values? The best answer, in my view, is to be found in Dworkin's Justice for Hedgehogs and Waldron's comments on it. Law is a domain of politics, and thus of morality, and thus of ethics. But it is a specialized domain. The "softness" of legal science and the disagreements that ripple through it do not compel (internal) scepticism. Although different from pure politics or philosophy, legal science nevertheless remains a normative one. A broad view of legal positivism takes this into account, without yet ignoring the specificity of the law's "moral" issues. ${ }^{292}$

\footnotetext{
${ }^{289}$ See Klug, supra note 153.

${ }^{290}$ Roberto Mangabeira Unger, “The Critical Legal Studies Movement”, (1983) 96:3 Harv L Rev 561 at 675.

${ }^{291}$ See Tamanaha, supra note 174, at 59. Tamanaha adds that "[t]his position, however, also renders the legal profession, judges in particular, uniquely situated to undermine the rule of law."

${ }^{292}$ See Waldron, "Jurisprudence for Hedgehogs", supra note 61, at 23 (arguing that "the part of morality that is law the part of morality that deals with the moral significance of past political events like precedents and enactments sometimes to consider the enactment of unjust statutes and the making of perverse or unfair decisions. It has to respond to political events that are unfortunate and that may have an impact on what is now morally required which we wish were not the case. Just because law is a branch of morality, it does not follow that what the law requires is morally perfect or never morally regrettable"), 25 (arguing that "[ $\mathrm{t}]$ he claim that law is part of morality does not require us to say that bad laws are not laws at all, or that bad laws are really good laws if only we could see. It does require us to say that in most cases when we are faced with enactments and precedents that morally frowns upon, we still have to try to figure out their significance along with all the rest of the corpus juris for our moral obligations") and 26 (arguing that "[m]aybe there are some laws that are so murderously wrong in their character that they have no impact on the moral situation at all - except to generate an obligation to resist them").
} 